\title{
Agroecological Responses of Heavy Metal Pollution with Special Emphasis on Soil Health and Plant Performances
}

\section{OPEN ACCESS}

Edited by:

Tripti Agarwal,

National Institute of Food Technology Entrepreneurship and Management,

India

Reviewed by:

Srinivasan Balachandran,

Visva-Bharati University, India

Naveen Kumar Singh,

Manipal University Jaipur, India

*Correspondence:

Rajeev P. Singh

rajeevprataps@gmail.com

Abhijit Sarka

abhijitbhu@gmail.com

Specialty section:

This article was submitted to

Environmental Toxicology

a section of the journal

Frontiers in Environmental Science

Received: 08 April 2017 Accepted: 29 September 2017

Published: 16 October 2017

Citation:

Srivastava V, Sarkar A, Singh S, Singh $P$, de Araujo ASF and Singh RP (2017) Agroecological Responses of

Heavy Metal Pollution with Special Emphasis on Soil Health and Plant

Performances.

Front. Environ. Sci. 5:64. doi: 10.3389/fenvs.2017.00064

\author{
Vaibhav Srivastava ${ }^{1}$, Abhijit Sarkar ${ }^{2 *}$, Sonu Singh ${ }^{3}$, Pooja Singh ${ }^{4}$, Ademir S. F. de Araujo ${ }^{5}$ \\ and Rajeev P. Singh ${ }^{1,6 *}$
}

${ }^{1}$ Department of Environment and Sustainable Development, Institute of Environment and Sustainable Development, Banaras Hindu University, Varanasi, India, ${ }^{2}$ Laboratory of Applied Stress Biology, Department of Botany, University of GourBanga, Malda, West Bengal, India, ${ }^{3}$ Ministry of Environment, Forest and Climate Change, Govt. of India, New Delhi, India, ${ }^{4}$ Society for Higher Education and Practical Applications, Varanasi, India, ${ }^{5}$ Soil Quality Laboratory, Agricultural Science Center, Federal University of Piaui, Teresina, Brazil, ${ }^{6}$ Department of Civil Engineering, University of Nebraska-Lincoln, Omaha, NE,

United States

With modern day urbanization and industrialization, heavy metal (HM) contamination has become a prime concern for today's society. The impacts of metal contamination on agriculture range from the agricultural soil to the produce in our food basket. The heavy metals (HMs) and metalloids, including $\mathrm{Cr}, \mathrm{Mn}$, Co, Ni, Cu, Zn, Cd, Sn, Hg, Pb, among others, can result in significant toxic impacts. The intensification of agricultural land use and changes in farming practices along with technological advancement have led to heavy metal pollution in soil. Metals/metalloids concentrations in the soil are increasing at alarming rate and affect plant growth, food safety, and soil microflora. The biological and geological reorganization of heavy metal depends chiefly on green plants and their metabolism. Metal toxicity has direct effects to flora that forms an integral component of ecosystems. Altered biochemical, physiological, and metabolic processes are found in plants growing in regions of high metal pollution. However, metals like Cu, Mn, Co, Zn, and $\mathrm{Cr}$ are required in trace amounts by plants for their metabolic activities. The present review aims to catalog major published works related to heavy metal contamination in modern day agriculture, and draw a possible road map toward future research in this domain.

Keywords: heavy metal, contamination, toxicity, soil health, plant metabolism, soil microflora

\section{INTRODUCTION}

Heavy metal contamination is a prime environmental concern that threatens plant, animal, and human health, as well as the quality of the environment. Like other metals and metalloids, heavy metals occur in the earth's crust, but due to their persistent and stable character, they cannot be degraded or destroyed. These heavy metals and metalloids are bioaccumulative and may slowly enter plants, animals, and humans through air, water, and the progression of the food chain over a certain period of time (Lenntech Water Treatment Air Purification, 2004; Nagajyoti et al., 2010). Heavy metal ores include sulfides of iron (Fe), lead $(\mathrm{Pb})$, zinc $(\mathrm{Zn})$, arsenic $(\mathrm{As})$, cobalt $(\mathrm{Co})$, silver $(\mathrm{Ag})$, gold $(\mathrm{Au})$, and nickel $(\mathrm{Ni})$; and oxides of aluminum $(\mathrm{Al})$, manganese $(\mathrm{Mn})$, gold $(\mathrm{Au})$, selenium $(\mathrm{Se})$, and antimony $(\mathrm{Sb})$. 
Also, some metals exist and can be retrieved both as sulfide and oxide ores such as iron $(\mathrm{Fe})$, copper $(\mathrm{Cu})$, and cobalt $(\mathrm{Co})$ (Duruibe et al., 2007; Alloway, 2013). Heavy metals are extracted from their ores during mineral processing. During this process, some parts are left in the open and transported to other places through wind and flood processes, creating severe threats to the environment (Lenntech Water Treatment Air Purification, 2004; Nagajyoti et al., 2010). Various natural and anthropogenic processes may release these heavy metals into the ambient environment (Dembitsky and Rezanka, 2003). Modern agricultural practices have caused agricultural pollution leading to degradation of the ecosystem and the environment due to increased application of agrochemicals and inorganic fertilizers (Malik et al., 2017). Additionally, land application of sewage sludge, organic waste manure, industrial byproducts, and irrigation with waste water are major sources of heavy metals into agricultural systems (Khan et al., 2013; Srivastava et al., 2016; Tóth et al., 2016; Sharma et al., 2017; Woldetsadik et al., 2017) (Figure 1).

Plants are subjected to biotic and abiotic stresses such as heat, cold, drought, high light intensity, UV radiations, heavy metals, and pollutants such as $\mathrm{O}_{3}$ and $\mathrm{SO}_{2}$ (Dezhban et al., 2015; Kumar et al., 2016). Consequently, high level of reactive oxygen species (ROS) like singlet oxygen $\left({ }^{1 / 2} \mathrm{O}_{2}\right)$, hydroxyl radical $\left(\mathrm{HO}^{\bullet}\right)$, superoxide radical $\left(\mathrm{O}_{2}^{\bullet-}\right)$, and hydrogen peroxide $\left(\mathrm{H}_{2} \mathrm{O}_{2}\right)$ are produced (Wang et al., 2015). Although, ROS are important signaling molecules that are generally in equilibrium with antioxidant molecules (D'Autréaux and Toledano, 2007; Holmström and Finkel, 2014; Reczek and Chandel, 2015; Mittler, 2017), but they may also pose adverse effect on organisms (Mates, 2000; Rhee et al., 2013; Shahid et al., 2014; Thakur et al., 2016). ROS could also affect various biochemical molecules, membrane lipids, amino acid chain, carbohydrates, proteins, pigments, and nucleic acids (Gratão et al., 2005; Manikandan et al., 2015; Venkatachalam et al., 2017). Moreover, membrane leakage accompanied by loss of cell metabolites from cell protoplasm is also caused by ROS (Dingjan et al., 2016) and may result in a reduction in cell growth or may even cause death in a few cases (Gonçalves et al., 2007; Lee et al., 2007).

It is evident that due to multiple social-economical, technological, and developmental issues, heavy metal contamination in modern day agriculture has become a serious crisis in most of the developing and under developed countries. Finding eco-friendly, sustainable ways to combat heavy metal contamination issue is a major challenge. The present review aims to catalog major published works related to heavy metal contamination in modern day agriculture, and draw a possible road map toward future research.
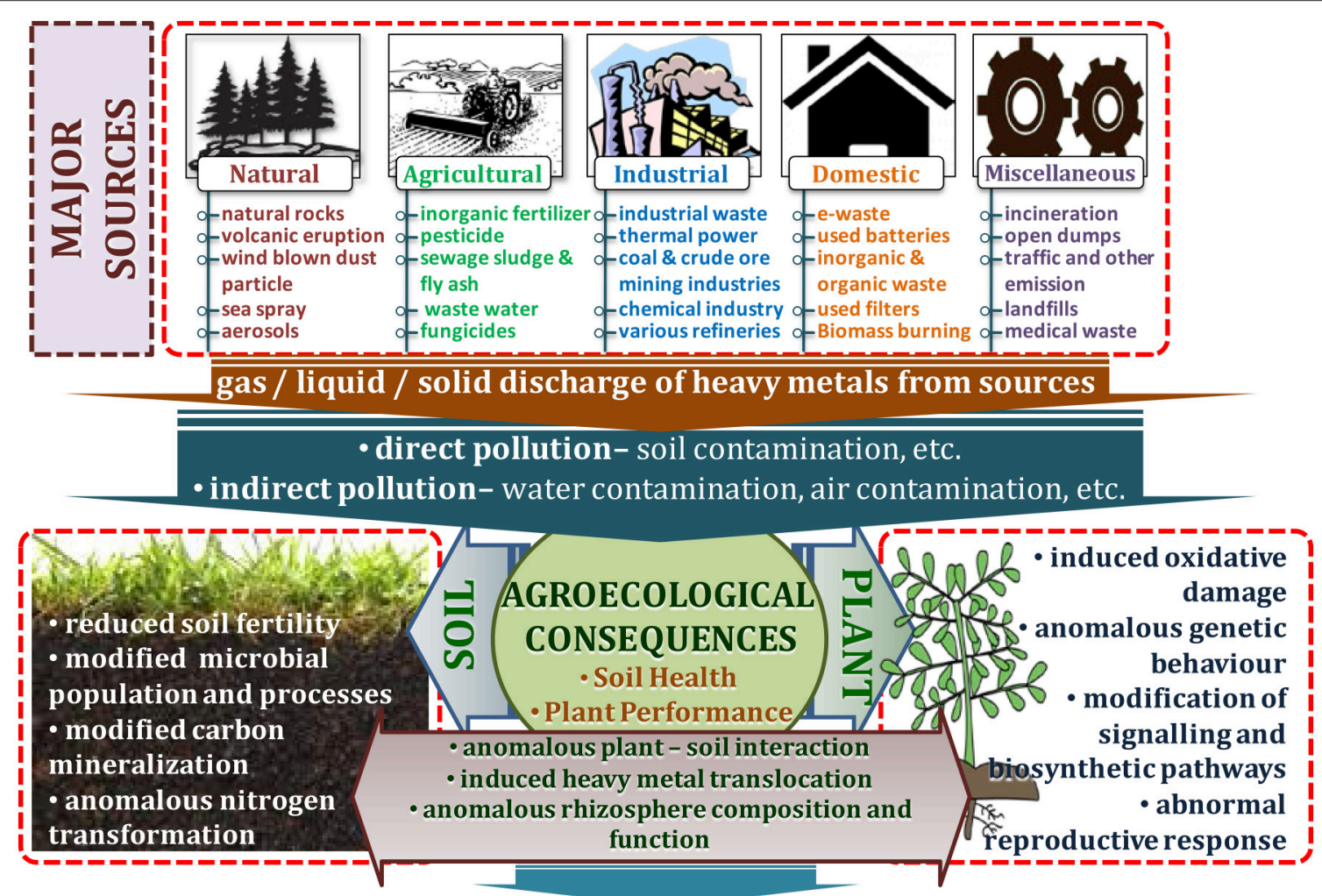

\section{REDUCED CROP PRODUCTION}

FIGURE 1 | Overview of sources of heavy metal pollution and its agroecological consequences. 


\section{NATURAL AND OTHER SOURCES OF HEAVY METALS IN AGRO-ENVIRONMENT}

\section{Natural Sources}

Weathering of rock is considered the most significant contributor of heavy metals. Generally, the weathering process is influenced by the nature of the rock and the environmental conditions on which the concentration and composition of heavy metals largely depends (Abdu et al., 2011). Materials of geologic origin have high concentrations of $\mathrm{Mn}, \mathrm{Cr}, \mathrm{Co}, \mathrm{Cu}, \mathrm{Ni}, \mathrm{Zn}, \mathrm{Sn}, \mathrm{Cd}, \mathrm{Hg}$, and $\mathrm{Pb}$. Volcanoes along with harmful and toxic gases are the highlevel emitters of $\mathrm{Al}, \mathrm{Zn}, \mathrm{Mn}, \mathrm{Pb}, \mathrm{Ni}, \mathrm{Cu}$, and $\mathrm{Hg}$ (Seaward and Richardson, 1989; Nagajyoti et al., 2010). Volcanic eruptions and windblown dust particles are also the source of heavy metals. High concentration of Fe and low amount of $\mathrm{Mn}, \mathrm{Zn}, \mathrm{Cr}, \mathrm{Ni}$, and $\mathrm{Pb}$ occurs from wind-dust blowing from the desert region like the Sahara (Ross, 1994; Nagajyoti et al., 2010). Similarly, marine aerosols and forest fires also contribute to environmental heavy metals to some extent. Fire produces volatile heavy metals like Se and Hg which are part of carbonaceous matter (Ross, 1994; Naidu et al., 1997; Nagajyoti et al., 2010). Natural vegetation contributes heavy metals to the environment through leaching, decomposition, and volatilization (Nagajyoti et al., 2010; Cuypers et al., 2013). Likewise, oceanic activities produce sea sprays and aerosols that contribute heavy metal into inland coastal areas (Zverina et al., 2014; Monge et al., 2015) (Figure 1).

\section{Agricultural Sources}

A major contributor of heavy metals in agricultural soil is inorganic fertilizers that also include liming, irrigation waters, and sewage sludge (Table 1). Varying concentrations of $\mathrm{Cd}$, $\mathrm{Cr}, \mathrm{Ni}, \mathrm{Pb}$, and $\mathrm{Zn}$ have been contributed by other sources, predominantly by fungicides, phosphate fertilizers, and inorganic fertilizers (Kelepertzis, 2014; Tóth et al., 2016) (Figure 1). Cadmium bioaccumulation in plants is of prime concern as it deposits on leaves at high concentration and that may be consumed by animals or humans. Sewage sludge, manure, limes is also the cause of cadmium enrichment (Yanqun et al., 2005; Niassy and Diarra, 2012). High levels of major heavy metals are reached in agricultural soil (where concentration is generally low) by repeated use of phosphate fertilizer (Verkleij, 1993; Carnelo et al., 1997). Sewage sludge adds $\mathrm{Cr}, \mathrm{Cu}, \mathrm{Zn}, \mathrm{Pb}, \mathrm{Ni}$, and $\mathrm{Cd}$ while animal manure augments the soil by adding $\mathrm{Mn}$, $\mathrm{Cu}, \mathrm{Zn}$, and Co (Verkleij, 1993). Land application of sewage sludge is one of the most important contributors of heavy metal in the soil (Singh and Agrawal, 2008; Araújo et al., 2010; Singh et al., 2011, 2012; Srivastava et al., 2015, 2016; Sharma et al., 2017). Several pesticides are also a major source of heavy metal contamination in agricultural fields (Ross, 1994; Wei and Yang, 2010; Tóth et al., 2016; Marrugo-Negrete et al., 2017). Table 2 shows the concentrations of heavy metals in different agricultural amendments. Similarly, waste water irrigation is also a major contributor of heavy metal pollution (Sharma et al., 2007; Khan et al., 2008, 2013; Qureshi et al., 2016; Islam et al., 2017; Woldetsadik et al., 2017). Therefore, concentrations or amounts of heavy metals in agricultural soil depend on soil characteristics and the composition and application rate of inorganic fertilizers, pesticides, sewage sludge, and/or waste water. Table 3 shows the permissible level of heavy metals in agricultural soil.

TABLE 1 | Sources of heavy metals in agricultural soil.

\begin{tabular}{|c|c|c|c|}
\hline \multicolumn{4}{|c|}{ Agricultural sources of heavy metals } \\
\hline Source & \multicolumn{2}{|l|}{ Heavy metal input } & References \\
\hline Fertilizers & $\begin{array}{l}\text { * Phosphate fertilizers } \\
\text { * Nitrate fertilizers } \\
\text { * Potash fertilizers } \\
\text { * Lime }\end{array}$ & $\begin{array}{l}\mathrm{Cr}, \mathrm{Cd}, \mathrm{Cu}, \mathrm{Zn}, \mathrm{Ni} \\
\mathrm{Mn} \text {, and } \mathrm{Pb}\end{array}$ & $\begin{array}{l}\text { Gimeno-García et al., 1996; Carnelo et al., 1997; Taylor and Percival, } \\
\text { 2001; Gray et al., 2003; Atafar et al., 2010; Sun et al., 2013; Kelepertzis, } \\
\text { 2014, etc. }\end{array}$ \\
\hline Pesticides & $\left.\begin{array}{l}\text { * Herbicides } \\
* \text { Insecticides } \\
\text { * Fungicides }\end{array}\right\}$ Primari $\mathrm{Pb}$ & $\begin{array}{l}\text { Primarily } \mathrm{Cu}, \mathrm{Zn} \text {, } \\
\mathrm{Cd}, \mathrm{Pb} \text {, and } \mathrm{As}\end{array}$ & $\begin{array}{l}\text { Gimeno-García et al., 1996; Gray et al., 2003; Nicholson et al., 2003; } \\
\text { Huang et al., 2007; Atafar et al., 2010; Fishel, 2014; Kelepertzis, 2014; } \\
\text { Tóth et al., 2016, etc. }\end{array}$ \\
\hline Biosolids and manure & $\left.\begin{array}{l}\text { * Livestock manures } \\
\text { * Composts } \\
\text { - Sewage sludge } \\
\text { *ly ash }\end{array}\right\}$ & $\begin{array}{l}\mathrm{Zn}, \mathrm{Cu}, \mathrm{Ni}, \mathrm{Pb} \\
\mathrm{Cd}, \mathrm{Cr}, \mathrm{As}, \text { and } \mathrm{Hg}\end{array}$ & $\begin{array}{l}\text { Nicholson et al., 2003; Singh and Agrawal, 2007, 2008, 2009, 2010a,b,c; } \\
\text { Singh et al., 2010, 2014; Chauhan et al., 2012; Niassy and Diarra, 2012; } \\
\text { Srivastava et al., 2015, 2016; Sharma et al., 2017, etc. }\end{array}$ \\
\hline Waste water & $\left.\begin{array}{l}\text { * Irrigation with municipal waste water } \\
* \text { Industrial waste water }\end{array}\right\}$ & oal waste water $\left\{\begin{array}{l}\mathrm{Zn}, \mathrm{Cu}, \mathrm{Ni}, \mathrm{Pb} \\
\mathrm{Cd}, \mathrm{Cr}, \mathrm{As} \text {, and } \mathrm{Hg}\end{array}\right.$ & $\begin{array}{l}\text { Nicholson et al., 2003; Marshall et al., 2007; Sharma et al., 2007; Khan } \\
\text { et al., 2013; Balkhair and Ashraf, 2016; Woldetsadik et al., 2017, etc. }\end{array}$ \\
\hline Atmospheric deposition & \multicolumn{2}{|c|}{$\begin{array}{l}\text { Mining, metal smelting and refining, manufacturing processes, } \\
\text { transport, and waste incineration: Primarily } \mathrm{Ni}, \mathrm{Cd}, \mathrm{Pb}, \mathrm{Cu}, \mathrm{Zn} \text {, } \\
\mathrm{Hg} \text {, and } \mathrm{Cr}\end{array}$} & $\begin{array}{l}\text { McLaughlin et al., 1999; Nicholson et al., 2003; Franco-Uría et al., 2009; } \\
\text { Cheng and Hu, 2010; Liu et al., 2014; Xu et al., 2014; Deng et al., 2016, } \\
\text { etc. }\end{array}$ \\
\hline
\end{tabular}


TABLE 2 | Heavy metal concentrations $\left(\mu \mathrm{g} \mathrm{g}^{-1}\right)$ in agricultural amendments (Adapted from Ross, 1994).

\begin{tabular}{|c|c|c|c|c|c|c|c|}
\hline \multirow[t]{2}{*}{ Metals } & \multicolumn{7}{|c|}{ Agricultural amendments } \\
\hline & Pesticides & Lime & Nitrate fertilizers & Phosphate fertilizers & Farmyard manure & Compost & Sewage sludge \\
\hline $\mathrm{Cr}$ & - & $10-15$ & $3.2-19$ & $66-245$ & $1.1-55$ & $1.8-410$ & $8.40-600$ \\
\hline $\mathrm{Ni}$ & - & $10-20$ & $7-34$ & $7-38$ & $2.1-30$ & $0.9-279$ & $6-5,300$ \\
\hline $\mathrm{Cu}$ & - & $2-125$ & - & $1-300$ & $2-172$ & $13-3,580$ & $50-8,000$ \\
\hline $\mathrm{Zn}$ & - & $10-450$ & $1-42$ & $50-1,450$ & $15-556$ & $82-5,894$ & $91-49,000$ \\
\hline $\mathrm{Cd}$ & - & $0.04-0.1$ & $0.05-8.5$ & $0.1-190$ & $0.1-0.8$ & $0.01-100$ & $<1-3,410$ \\
\hline $\mathrm{Pb}$ & $11-26$ & $20-1,250$ & $2-120$ & $4-1,000$ & $0.4-27$ & $1.3-2,240$ & $2-7,000$ \\
\hline
\end{tabular}

TABLE 3 | Permissible limit of heavy metals in agricultural soil.

\begin{tabular}{lcc}
\hline Heavy metals $\mathbf{~ ( m g ~ k g ~}^{-\mathbf{1}}$ ) & \multicolumn{2}{c}{ Standards } \\
\cline { 2 - 3 } & $\begin{array}{c}\text { Indian standards } \\
\text { (Awasthi, 1998) }\end{array}$ & $\begin{array}{c}\text { European union standards } \\
(\mathbf{E U}, \mathbf{2 0 0 2})\end{array}$ \\
\hline $\mathrm{Cr}$ & - & 150 \\
$\mathrm{Mn}$ & - & - \\
$\mathrm{Cu}$ & $135-270$ & 140 \\
$\mathrm{Zn}$ & $300-600$ & 300 \\
$\mathrm{Ni}$ & $75-150$ & 75 \\
$\mathrm{Cd}$ & $3-6$ & 3 \\
$\mathrm{~Pb}$ & $250-500$ & 300 \\
\hline
\end{tabular}

\section{Industrial Sources}

Different industrial activities like mining and refinement are another major sources of heavy metal contamination (Figure 1). Mining activities emits various types of heavy metals which depend on the nature of mining practices used. For example, the use of $\mathrm{Hg}$ in gold mines has become a major contributor of this metal into the environment (Clemens and Ma, 2016; Pavilonis et al., 2017). Similarly, coal mines are the chief source of As, Cd, and Fe which can pollute adjacent soil. Vaporized heavy metals like $\mathrm{Cu}, \mathrm{Zn}, \mathrm{Pb}, \mathrm{As}, \mathrm{Sn}$, and $\mathrm{Cd}$ combine with water and condense to form aerosols (Nagajyoti et al., 2010). These may be either dry deposited (dispersed by winds) or wet deposited (precipitated in the form of rainfall) causing water and soil contamination. Similarly, waste runoff from mines, dust from transportation of crude ores, corrosion and leaching of heavy metals also contaminate soil and water bodies (Carlisle and Clements, 2005; Vásquez-Murrieta et al., 2006; Alloway, 2013; Rout et al., 2013). Various refinery processes also contribute to heavy metal pollution in the soil. Heavy metals like B, Se, $\mathrm{Cu}, \mathrm{Zn}, \mathrm{Cd}, \mathrm{Ni}$, and $\mathrm{Cs}$ are emitted by petroleum industries, coal burning power stations, nuclear power stations, and hightension wires (Verkleij, 1993; Ahmed and Ahmaruzzaman, 2016; Zhu et al., 2016). Another contributor of heavy metal pollution includes processing of plastic, paper, textiles, electronics, and wood preservation. Antiwear protectants for automobiles release $\mathrm{Pb}, \mathrm{Cd}, \mathrm{Ni}, \mathrm{Hg}, \mathrm{Cr}$, and $\mathrm{Zn}$ especially in inefficient engines. The combustion lead containing gasoline emits $\mathrm{Pb}$ in the atmosphere and incinerators for MSW produces a considerable amount of $\mathrm{Zn}, \mathrm{Pb}, \mathrm{Al}, \mathrm{Sn}, \mathrm{Fe}$, and $\mathrm{Cu}$.

\section{Domestic Sources}

Effluents are most probably the largest contributor of the high concentration of metal found in ponds, lakes, and rivers (Zahra et al., 2014; Singh and Kumar, 2017). Effluents generally consist of (1) mechanically treated or untreated wastewater, (2) materials that have passed from the filters of biological treatment plants, and (3) waste material from sewage outfall which is discharged into water bodies like the sea. Urban runoff also presents a severe problem of heavy metal pollution (Figure 1).

\section{Miscelleneous Sources}

Other contributors of heavy metal pollution are comprised of refuse from incineration, industrial discharge, transportation or traffic emisssions, and open dumps or landfills (Singh et al., 2011; Srivastava et al., 2015; Aryal et al., 2017; Dubey et al., 2017). Vehicular sources include $\mathrm{Zn}$ and $\mathrm{Cd}$ associated with dust from tire wear (Gope et al., 2017), Cu and Cd from diesel engines (Nagajyoti et al., 2010), and $\mathrm{Cr}, \mathrm{Ni}$ and $\mathrm{Zn}$ from aerosol emissions (Chen et al., 2013).

\section{AGROECOLOGICAL RAMIFICATIONS OF HEAVY METALS CONTAMINATION}

\section{Soil Health and Fertility}

Management of good soil quality is a key factor for sustainable agriculture and soil biology plays an important role. Soil microbes are an essential component of the ecosystem (Harris, 2009). Microorganisms play a key role in maintaining soil fertility via organic matter disintegration and nutrient cycling. However, they can be negatively affected when exposed to stress factors like extreme temperature, $\mathrm{pH}$, salinity, and chemical pollution (Schimel et al., 2007; Paz-Ferreiro and Fu, 2016). The soil may become contaminated with heavy metals from various anthropogenic activities including industrial, mining, and agricultural activities. For example, heavy metals present in wastes from mines, sewage sludge, inorganic fertilizers, and pesticides may enter into the soil system and affect microbes (Carlisle and Clements, 2005; Gupta et al., 2010; Tóth et al., 2016; Sharma et al., 2017).

\section{Soil Microbial Dynamics}

Microbial viability decreases with increasing levels of heavy metal contamination. For example, Greszta et al. (1979) found decreased colony forming units (CFUs) of bacteria and fungi 
in the forest soil mixed with $\mathrm{Pb}-\mathrm{Cu}$ sludge, $\mathrm{Pb}-\mathrm{Cu}$ dust, $\mathrm{Pb}-\mathrm{Zn}$ dust, and Cd-Pb-Zn. Freedman and Hutchinson (1980) observed a significant decrease in fungal CFUs near Sudbury smelters however, the results were not statistically significant from the non-polluted sites. Brookes and McGrath (1984) observed the effect of sewage sludge $\left(\mathrm{Cu}=40-90 \mu \mathrm{g} \mathrm{g}{ }^{-1}\right.$, Ni $=5-10 \mu \mathrm{g}$ $\mathrm{g}^{-1}$ ) amended agricultural soil for a period of 20 years and noticed decreased soil microbial biomass. Likewise, Rühling et al. (1984) found a decreased number of species of fruitbody producing fungi with increasing proximity to Gusum smelter and found about 35 species at control sites $\left(<100 \mu \mathrm{g} \mathrm{Cu} \mathrm{g}^{-1}\right.$ organic matter), about 25 species in moderately polluted $(<1,000$ $\mu \mathrm{g} \mathrm{Cu} \mathrm{g}{ }^{-1}$ organic matter), and 13 species near the smelter $\left(<1,000 \mu \mathrm{g} \mathrm{Cu} \mathrm{g}^{-1}\right.$ organic matter). Šmejkalová et al. (2003) observed decreased CFU of total bacteria and micromycetes with increasing heavy metal concentration. Yuan et al. (2015) reported a negative correlation of microbial viability to extended exposure to $\mathrm{Pb}$. Similarly, dos Santos et al. (2016) studied the biological soil attributes in a heavy metal contaminated site located in close proximity to the Votorantim Metal Company in the municipality of Três Marias (MG), Brazil. They reported decreased CFU of bacteria $\left(5.5 \times 104 \mathrm{~g}^{-1} \mathrm{dry}\right.$ soil $)$, actinobacteria $\left(1.4 \times 102 \mathrm{~g}^{-1}\right.$ dry soil $)$, and fungi $\left(2.0 \times 104 \mathrm{~g}^{-1}\right.$ dry soil $)$ in heavy metal contaminated site as compared to control site (CFUs were $2.0 \times 107,1.1 \times 105,5.0 \times 104 \mathrm{~g}^{-1}$ dry soil for bacteria, actinobacteria, and fungi respectively). de Quadros et al. (2016) demonstrated a reduction in microbial biomass, richness, and diversity due to coal mining practices. Nayak et al. (2015) reported that 40 and $100 \%$ fly ash amendments increased the concentrations of $\mathrm{Zn}, \mathrm{Fe}, \mathrm{Cu}, \mathrm{Mn}, \mathrm{Cd}$, and $\mathrm{Cr}$ in agricultural soils, and also affected the microbial population dynamics. They also reported that microorganisms differed in their responses to the rate of fly ash amendments. The population of both fungi and actinomycetes decreased by the application of fly ash, while the aerobic heterotrophic bacterial population did not change significantly up to $40 \%$ fly ash amendment. On the other hand, total microbial activity measured in terms of fluoresceindiacetate (FDA) assay, and denitrifiers showed an increasing trend up to $40 \%$ fly ash amendment. However, the activities of both alkaline and acid phosphatase were decreased by the application of fly ash. Likewise, Wang et al. (2007) demonstrated that heavy metals pollution had a significant impact on soil bacterial and actinomycetic community structure through the use of Polymerase chain reactiondenaturing gradient gel electrophoresis (PCR-DGGE) technique. According to their findings, negative correlations were observed between soil microbial biomass, phosphatase activity, and heavy metals concentrations. Also, soil microorganisms activity and community composition could be predicted using the availability of $\mathrm{Cu}$ and $\mathrm{Zn}$. Effect of heavy metals on soil enzyme activities are given in Table 4.

\section{Soil Microbial Functions and Processes}

\section{A. Litter decomposition}

Heavy metal toxicity leads to reduced litter decomposition resulting in unrecompensed litter layer on the soil (Illmer and Schinner, 1991; Giller et al., 1998; Marschner and
Kalbitz, 2003). Bringmark and Bringmark (2001) reported a significant correlation between respiration rates from forest litter and concentrations of lead $(\mathrm{Pb})$ in soil organic layers at concentrations not much higher than those typical for uncontaminated areas. Similarly, the decomposition rate of mountain birch (Betula pubescens ssp. Czerepanovii) leaves were examined by Kozlov and Zvereva (2015) in a heavily polluted industrial area near the nickel-copper smelter in Monchegorsk. A significant reduction of $49 \%$ was found in relative mass loss of native leaves compared with the loss noted in unpolluted forest during 2 years of exposure. Also, microbial activity in soil was reduced by four-fold and almost complete extinction of saprophagous invertebrates was identified in the polluted soil. They concluded that the slow decomposition rate of birch leaves in an industrial barren resulted primarily due to high metal concentration in both soil and litter and from drastic environmental changes associated with the forest decline. Moreover, a number of studies have shown that anthropogenic heavy metal pollution poses adverse effect on litter decomposition in streams (Carlisle and Clements, 2005; Hogsden and Harding, 2012; Ferreira et al., 2016). For example, Zn from abandoned mines in the western United States pollutes nearby streams, thereby adversely affects the microbial fauna of streams and interferes with litter breakdown (Carlisle and Clements, 2005).

\section{B. Carbon mineralization}

The rate of soil organic carbon mineralization has been widely used as an assay for metal toxicity in both ecotoxicological and environmental monitoring studies (Giller et al., 1998). The soil respiration rate can be used to assess carbon mineralization. Usually, low concentrations of heavy metal have a slight effect on soil respiration, but the effect is decreased with increasing heavy metal pollution or toxicity. A number of studies suggest that heavy metal addition often results in a decreased respiratory rate for a wide range of substrates like cellulose (Hattori, 1992), glucose (Mikkelsen, 1974; Hattori, 1991), plant residues (Aoyama and Itaya, 1995), and sewage sludge (Dar and Mishra, 1994). Tyler (1975) reported a reduced decomposition rate of starch and cellulose in heavy metal polluted soil, while a negligible effect was seen for protein and glucose. By the 6th week post-treatment, the rates of carbon accumulated were high in the copper $(6.03 \%)$ and copper: Zinc (5.80\%) treatments, but low in the nickel and zinc (4.93 and 5.02\% respectively). Nwuche and Ugoji (2008) observed a negative correlation between soil microbial respiration and heavy metal content. The rate of soil microbial respiration was reduced to $0.98,1.08$, and $1.61 \mu \mathrm{g}$ of $\mathrm{C} / \mathrm{g}$ in the $\mathrm{Cu}: \mathrm{Zn}, \mathrm{Cu}$, and $\mathrm{Zn}$ treated soil respectively from an average rate of $2.51-2.56 \mu \mathrm{g}$ of $\mathrm{C} / \mathrm{g}$ at the beginning of the experiment. Reductions in respiration rate resulted in declined carbon mineralization and led to cabon accumulation. Among different treatments, $\mathrm{Cu}$ had the highest carbon accumulation (6.03\%) followed by $\mathrm{Cu}: \mathrm{Zn}(5.80 \%)$ and $\mathrm{Cu}: \mathrm{Ni}(5.36 \%)$ treated soil from an average value of $4.87 \%$ at the beginning of the experiment. Vásquez-Murrieta et al. (2006) showed a negative correlation between $\mathrm{C}$ minerlization and the heavy metal (As, $\mathrm{Pb}, \mathrm{Cu}$, and $\mathrm{Zn}$ ) content of the soil from mine spills in San Luis Potosí (Mexico). Similarly, reduction in carbon 


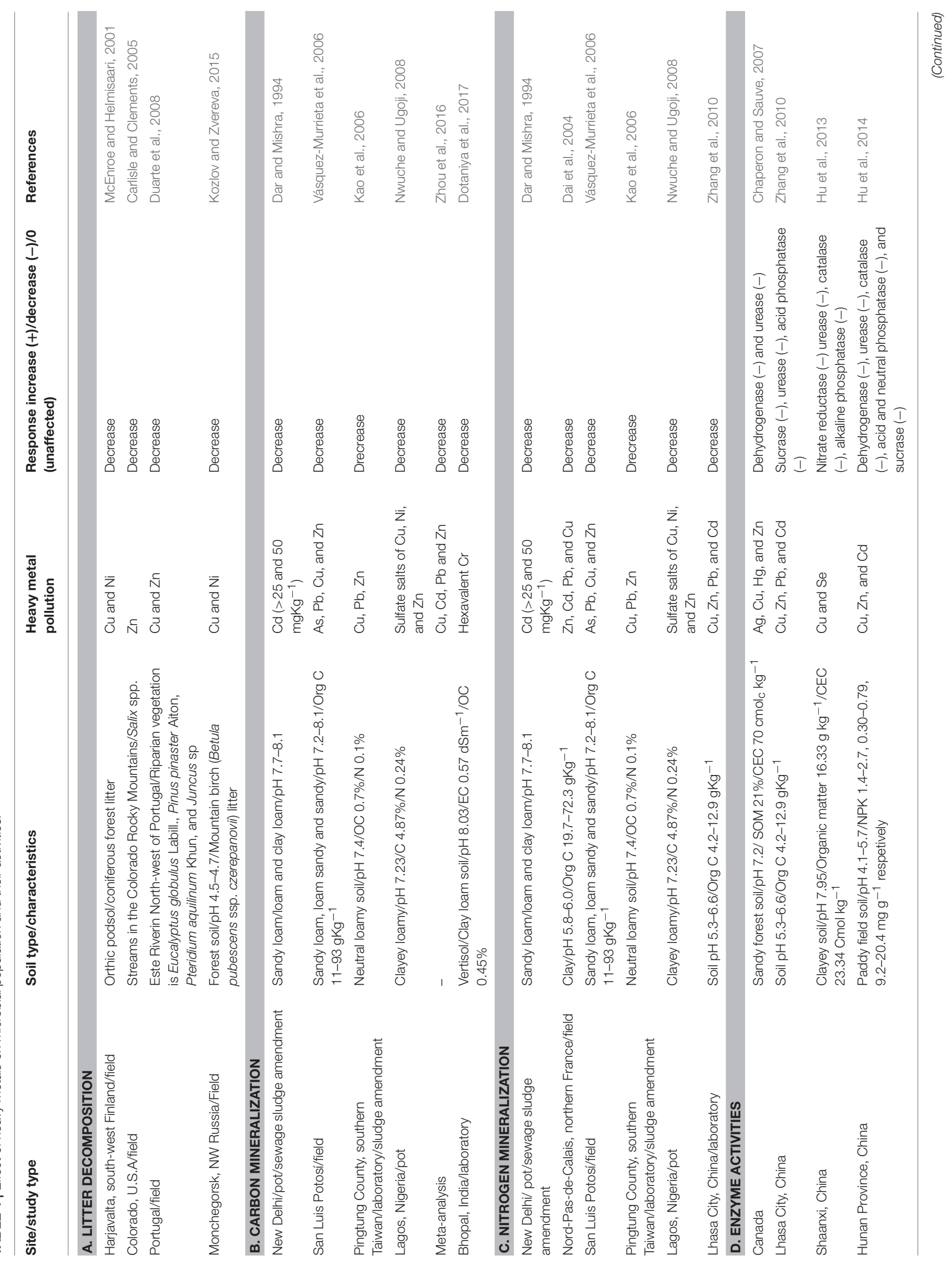




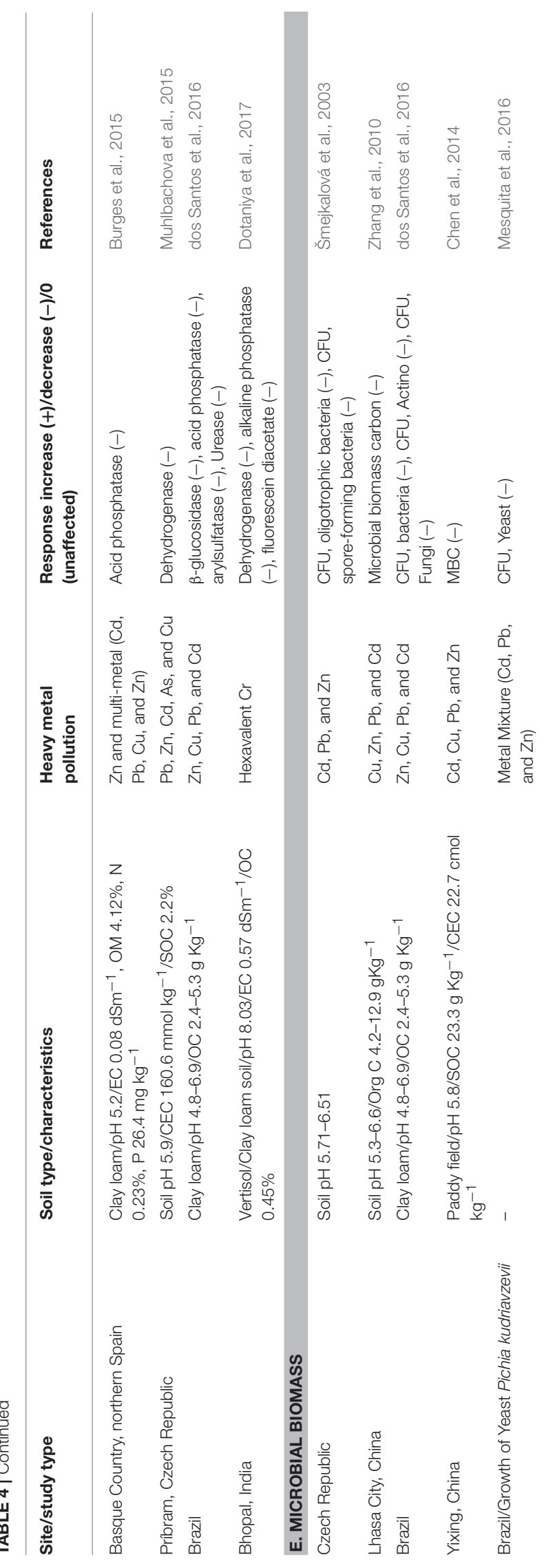

mineralization was noticed in a clay loam soil when subjected to hexavalent chromium (Dotaniya et al., 2017).

\section{Nitrogen transformations}

Heavy metal application can induce or inhibit N-mineralization that may be due to discrepancies in experimental procedure adopted, variation in soil properties and substrate concentrations. Generally, heavy metal pollution has a negative impact on nirogen transformation processes, which in turn affects N- mineralization (Dai et al., 2004; Vásquez-Murrieta et al., 2006; Zhang et al., 2010; Hamsa et al., 2017). Tyler (1975) reported decreased $\mathrm{N}$-mineralization at very low $\mathrm{Cu}(100 \mu \mathrm{g}$ $\mathrm{g}^{-1}$ ) concentration in the soil. The impact on nitrification is similar to that of $\mathrm{N}$-mineralization after heavy metal exposure (i.e., with increasing concentration of heavy metals nitrification decreases and vice versa) (De Catanzaro and Hutchinson, 1985). Also, in most of the cases nitrification seems to be more sensitive to heavy metal pollution than N-mineralization (Rother et al., 1982; Bewley and Stotzky, 1983). Brookes et al. (1986) reported a significant decrease of $50 \%$ in $\mathrm{N}_{2}$ fixation rate for blue green algae grown on sludge amended soil with low concentrations of

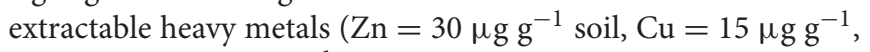
$\mathrm{Ni}$ and $\mathrm{Cd}=2 \mu \mathrm{g} \mathrm{g}^{-1}$ ). Similarly, Nwuche and Ugoji (2008) studied the effects of heavy metals on soil microbial processes over a period of 6 weeks. The results showed that $\mathrm{Cu}$ and $\mathrm{Cu}: \mathrm{Zn}$ $(P<0.05)$ significantly ineterered with microbial nitrogen mineralization and caused accumulation of $\mathrm{N}$ in the soil. At the end of the experiment $\mathrm{N}$ content was 0.41 and $0.44 \%$ in $\mathrm{Cu}$ and $\mathrm{Cu}: \mathrm{Zn}$ treated soil as compared to $0.23 \%(\mathrm{Cu})$ and $0.24 \%$ $(\mathrm{Cu}: \mathrm{Zn})$ at the beginning of the experiment. Similar results were reported by Dai et al. (2004) where the wastes disposal of metallurgic industry in Nord-Pas-de-Calais, northern France led to heavy metal contamination $(\mathrm{Zn}, \mathrm{Pb}, \mathrm{Cu}$, and $\mathrm{Cd})$ and reduced $\mathrm{N}$ mineralization. Likewise, Zhang et al. (2010) observed reduced $\mathrm{N}$ mineralization in heavy metal contaminated mining soil at the Lawu mine of central Tibet, China.

\section{Soil Enzymes}

The bioavailability of metals in soils depend on metal contents, soil $\mathrm{pH}$, organic matter, and clay content. Soil enzyme activities such as arylsulfatase, alkaline phosphatase, bglucosidase, cellulase, dehydrogenase, invertase, protease, and urease are sensitive to the presence of heavy metals (Oliveira and Pampulha, 2006; Wang et al., 2008; Hu et al., 2013, 2014; Burges et al., 2015; Xian et al., 2015). Oliveira and Pampulha (2006) assessed the effect of heavy metals on soil microbiology and biochemistry in an area with a known history of pollution. The heavy metal concentration in soil was reported to be 1,558 and $109 \mathrm{mg} / \mathrm{kg}$ for As and $\mathrm{Hg}$ respectively. The pollution led to decreases in microbial activity and soil dehydrogenase activity. Similarly, the addition of MSW composts in soil led to decreased urease and protease activity that might have been due to the heavy metal induced toxicity present in the municipal solid waste (Garcia-Gil et al., 2000; Crecchio et al., 2004). Likewise, the application of different rates of $\mathrm{Cd}, \mathrm{Pb}$, and $\mathrm{Cd} / \mathrm{Pb}$ mixture in soil reduced the activities of acid phosphatase (ACP), urease (URE), and microbial biomass carbon (MBC). The maximum 
reduction of $35.6 \%$ (ACP), 36.6\% (URE), and $52.4 \%$ (MBC) was noticed in $\mathrm{Cd} / \mathrm{Pb}$ treated samples in comparison to control. The DGGE profiling also revealed that addition of metals significantly affected the microbial community structure (Khan et al., 2010). Moreover, heavy metals can significantly affect the soil ecosystems and biological activity in the soil. In their study, Pan and Yu (2011) shown that the heavy metals (Cd or/ and $\mathrm{Pb}$ ) negatively affect the activity of soil enzymes like acid phosphatase, urease, and dehydrogenase and also lowered the soil microbial population. Hu et al. (2013) investigated individual and combined effects of $\mathrm{Cu}$ and Se on soil enzyme activities in a lab-scale experiment. The results showed a negative correlation of four soil enzymes (urease, alkaline phosphatase, catalase, and nitrate reductase) to $\mathrm{Cu}$ and Se pollution, either singly or combined. The activity was found in order of nitrate reductase $>$ urease $>$ catalase $>$ alkaline phosphatase. Hu et al. (2014) found reduced soil enzyme activities and microbial biomass in three heavily polluted paddy fields distributed in three different towns of Y County, northern Hunan Province. All three fields were badly polluted by heavy metals ( $\mathrm{Cu}, \mathrm{Zn}$, and $\mathrm{Cd}$ ) due to long term irrigation with contaminated water due to mining activities. The $\mathrm{MBC}$ and $\mathrm{MBN}$ in one of the severely polluted sites declined to 31.6 and $64.4 \%$ of the controls, respectively. Whereas, activities of acid phosphatase, catalase, dehydrogenase, sucrose, and urease were $94.7,52.4,25.2,87.8$, and $49.3 \%$ of the controls, respectively. Likewise, b-glucosidase and acid phosphatase activities were reduced significantly under repeated single-metal and multimetal $(\mathrm{Pb}, \mathrm{Cu}, \mathrm{Zn}, \mathrm{Cd})$ pollution events on soil quality (Burges et al., 2015). Xian et al. (2015) assessed the joint effect of heavy metals and soil properties on soil activities and found that arylsulfatase is the most sensitive soil enzyme that could be used as an indicator for soil toxicity. Soil organic matter (SOM) is the dominant factor affecting the activity of arylsulfatase and when it is present above the critical level, then it minimizes the noxious effect of heavy metal and enhances soil microbial activity.

\section{Plant Responses}

Heavy metal pollution is one of the contemporary environmental issues contaminating water, air and soil. This not only leads to substantial losses in crop productivity, but also poses health hazards. When plants are exposed to heavy metal stress, then it provokes antioxidative systems of plants in order to minimize the damage (Figure 1). The current section deals with heavy metalplant interaction and different physiological and biochemical responses of plants.

\section{Oxidative Stress and ROS}

"Reactive oxygen species" are chemically reactive species derived from molecular oxygen. Several different ROS are present transiently in all aerobic organisms, including: (a) oxygen derived non-radicals e.g., hydrogen peroxide $\left(\mathrm{H}_{2} \mathrm{O}_{2}\right)$, singlet oxygen $\left({ }^{1 / 2} \mathrm{O}_{2}\right)$, organic hydroperoxide $(\mathrm{ROOH})$; and $(\mathrm{b})$ oxygen derived free radicals e.g., hydroxyl $\left(\mathrm{HO}^{\bullet}\right)$, peroxyl $\left(\mathrm{RO}_{2}^{\bullet}\right)$, superoxide anion $\left(\mathrm{O}_{2}^{\bullet-}\right)$, and alkoxyl $\left(\mathrm{RO}^{\bullet}\right)$ radicals (Pinto et al., 2003; Circu and Aw, 2010; Shahid et al., 2014; Tamás et al., 2017). Usually, ROS are natural byproducts of the oxidative metabolism that may pose damage to all aerobic organisms. Although some of them are known to be as important signaling molecules that have the potential to modulate the activity of specific defense proteins. ROS are highly unstable and reactive molecules having a very short life (Wang et al., 2010) that can oxidize proteins, lipids, and nucleic acids leading to cell structure alteration and mutagenesis (Malar et al., 2014; Manikandan et al., 2015, 2016; Venkatachalam et al., 2017). In photosynthetic organism's organelles like chloroplast, mitochondria, and peroxisomes are considered to be the centers of ROS production (Pinto et al., 2003; Pucciariello et al., 2012). Exposure of plants to toxic heavy metals leads to increased production of ROS as heavy metals interact with electron transport activities of chloroplast and mitochondrial membrane. ROS can disrupt the redox status of cells posing damage to the membrane resulting in ion leakage (Dingjan et al., 2016; Anjum et al., 2017). Also, it causes lipid peroxidation and biological macromolecule breakdown (Carrasco-Gil et al., 2012; Chen et al., 2012; Venkatachalam et al., 2017). The stage of plant physiological challenge developed due to an imbalance or disturbance between ROS formation and removal through antioxidative defense mechanism is known as oxidative stress (Kovácik et al., 2010; Morina et al., 2010; Manikandan et al., 2015; Venkatachalam et al., 2017). Anjum et al. (2017) reported increased levels of $\mathrm{Cr}$ toxicity in two genotypes of maize led to high proline, phenolic, and soluble sugar contents, and low soluble protein content. Increases in malondialdehyde and $\mathrm{H}_{2} \mathrm{O}_{2}$ content led to electrolyte leakage.

\section{Genotoxicity}

The mechanisms behind metal induced genotoxicity are complex in nature and still not well-understood (Cuypers et al., 2011; Shen et al., 2013). It has been determined that heavy metal induced genotoxicity/DNA damage occurs indirectly through the production of ROS under oxidative stress (Barbosa et al., 2010; Shahid et al., 2014; Malar et al., 2015; Aslam et al., 2017) (Figure 1). Heavy metal toxicity induces chromosomal aberrations and also decreases the cell division rate. A number of studies have previously identified heavy metal induced nucleic acid impairments in plants like Allium cepa (Steinkellner et al., 1998; Barbosa et al., 2010; Arya et al., 2013; Arya and Mukherjee, 2014; Qin et al., 2015), Vicia faba (Qun and Xiao, 1995; Steinkellner et al., 1998; Marcato-Romain et al., 2009; Pourrut et al., 2011; Arya et al., 2013; Arya and Mukherjee, 2014), Helainthus annuus (Chakravarty and Srivastava, 1992), Solanum tuberosum, and Nicotiana tabacum (Gichner et al., 2006) etc. Genotoxic responses differ among plant species to the same metal and usually depends on the number and total length of the diploid chromosomes and also the number of metacentric chromosomes (Ma et al., 1995; Patra et al., 2004). The concentration of heavy metal, its oxidation state and extent of exposure greatly affects the genotoxic response of any plant (Malar et al., 2015; Aslam et al., 2017). Hydroxyl radical $\left(\mathrm{OH}^{\bullet}\right.$ ) is the highly reactive species among ROS, damaging all the components of the DNA molecule (Jones et al., 2011). ROS interaction with DNA leads to base deletion, base modification, strand breaks, and damages to cross links and pyrimidine dimers (Gastaldo et al., 2008). There are four different potential sites for metal binding in DNA viz. (i) the ribose hydroxyls; (ii) the 
exocyclic base keto groups, (iii) the negatively charged phosphate oxygen atoms; and (iv) the base ring nitrogens (Oliveira et al., 2008). A promutagenic damage caused by metal binding to the cell nucleus leads to DNA base modifications, inter- and intra-molecular cross-linking of DNA and proteins, DNA strand breaks, rearrangements, and de-purination (Kasprzak, 1995). Oxidized bases are usually generated upon the interaction of ROS with DNA and 8-oxoguanine is the most abundant and studied form modified DNA bases (Fortini et al., 2003) that may cause neoplastic transformation (Bal and Kasprzak, 2002). Cunningham (1997) reported that a promutagenic adduct 7,8-dihydro-8-oxoguanine (8-OxoG) is generated due to ROS interaction with DNA that have the ability to pair with adenine causing C to T transversion mutations. Yang et al. (1999) observed generation in 8-hydroxydeoxyguanosine (8-OHdG) adducts when $\mathrm{Cd}$ and $\mathrm{Pb}$ interacted with DNA lead in strand breakage. Similarly, Hirata et al. (2011) identified Cr and As induced translesion DNA synthesis resulting due to generation of 8-OHdG.

Qin et al. (2015) studied genotoxic effects of copper $(\mathrm{Cu})$ in root tip cells of A. cepa var. agrogarum L. The exposure to ionization $\mathrm{Cu}$ led to reduced mitotic index and chromosomal aberrations (viz. C-mitosis, chromosome stickiness, chromosome bridges, and micro nucleus). Also, $\mathrm{Cu}$ toxicity caused impaired microtubules arrangement at different concentrations and decreased content of $\alpha$-tubulin in comparison to controls. Venkatachalam et al. (2017) reported $\mathrm{Pb}$ induced genotoxicity due to the amplification of new bands and absence of normal amplicons in treated plants in random amplified polymorphic DNA (RAPD) analysis. Likewise, when seeds and seedlings of Lactuca sativa were subjected to increasing levels of $\mathrm{Pb}\left(\mathrm{NO}_{3}\right)_{2}$ (2-20 $\mathrm{mg} \mathrm{l}^{-1}$ ), higher doses caused DNA fragmentation (>5 mg $\left.\mathrm{1}^{-1}\right)$, and the presence of micronuclei $\left(20 \mathrm{mg}^{-1}\right)$. Also, cell cycle impairment was observed even under low $\mathrm{Pb}$ doses ( 0.05 and 0.5 $\mathrm{mg}^{-1}$ ) (Silva et al., 2017).

\section{Interference with Signaling Pathways}

The mechanisms explaining how heavy metals affect the cell signaling are still poorly understood. Cell signaling process may be directly affected during the interaction of heavy metals with proteins or indirectly during formation of the metalinduced ROS (Foyer and Noctor, 2005; Mittler et al., 2011; Islam et al., 2015) (Figure 1). Studies suggest that dysregulation of the signaling events caused by heavy metal interactions are the main reason for heavy metal toxicity and its negative impacts. Cellular interactions with the heavy metals leads to changes in various significant processes like regulation of gene expression, interference with signaling processes by affecting the G-proteins, growth factor receptors, and receptor tyrosine kinases (Harris and Shi, 2003). Signal transduction under stress is a complex process that starts with the plant sensing the heavy metal followed by activation of responsive genes by transcription, ultimately reducing the deleterious effect on plants (Maksymiec, 2007). Activation of stress related genes are involved in certain signal transduction pathways such as mitogen-activated protein kinase (MAPK) phosphorylation, ROS signaling system, Ca-calmodulin, and hormones (Islam et al.,
2015). Numerous studies have shown that in plants heavy metals like $\mathrm{Cu}, \mathrm{Zn}, \mathrm{Pb}$, and $\mathrm{Cd}$ can affect the mitogen kinase signaling pathways (Xiong and Yang, 2003; Nakagami et al., 2005). The generally affected pathways include MAPK pathways as they are activated by ROS and are easily affected by various signaling stimuli (Zhang and Klessig, 2001; Yeh et al., 2003; Rodriguez et al., 2010). Jonak et al. (2004) reported that in Medicago sativa, MAPK pathways were reported to be rapidly activated with increased concentration of $\mathrm{Cu}$. However, the same pathway was delayed with Cd exposure (Jonak et al., 2004). Heavy metals also increase the level of $\mathrm{H}_{2} \mathrm{O}_{2}$ generation by enhancing the synthesis of salicylic acid (SA), jasmonic acid (JA), and ethylene (ET) in plants and this in turn interferes with the cell signaling process (Maksymiec, 2007; Schellingen et al., 2014; Van de Poel et al., 2015). For example, the elevated levels of JA during As exposure of plants promotes the expression of some signaling and stress responsive genes like MAPK, CDC25 and those responsive to glutathione metabolism (Agrawal et al., 2003; Thapa et al., 2012; Islam et al., 2015).

\section{Physiological and Biochemical Response}

Heavy metals interact with structural components (cell, tissue, and organs) either directly or indirectly by modulating cell signaling or metabolism that appears in the form of visible injuries (Shahid et al., 2014). Studies at both structural and substructural level will help to identifying the sites of primary heavy metal toxicity and better understanding of their consequences on plant response. In order to combat with metal phyto-toxicity, plants have evolved an anti-oxidative defense system having many enzymes such as those of ascorbate peroxidase (APX), catalase (CAT), superoxide dismutase (SOD), glutathione (GSH), glutathione reductase (GR), peroxidase (POX), and guaiacol peroxidase (GPX), which play a pivotal role in scavenging excess ROS (Zhang et al., 2007; Li et al., 2012, 2013; Hattab et al., 2016; Sidhu et al., 2016; Venkatachalam et al., 2017) (Figure 1).

Zhang et al. (2007), examined the effect of heavy metal stress on two mangrove plants found increased ROS as evidenced by MDA production. Similar results were obtained in a number of studies done in the past on higher plants (Singh and Agrawal, 2007; Zhang et al., 2007; Sidhu et al., 2016; Alves et al., 2017). This suggests that free radicals play a significant role in heavy metal induced toxicity of higher plants. Likewise, superoxide dismutase (SOD) activity was improved significantly in roots and leaves at low heavy metal concentration, however its activity was decreased sharply at high concentrations indicating impairment of SOD scavenging function. Similar results were noticed in Allium sativum (Zhang et al., 2005) and Alyssum species (Schickler and Caspi, 1999). SOD activity peaked in roots of Kandelia candel at higher doses of heavy metal than in roots of Bruguiera gymnorrhiza suggesting better tolerance ability of $K$. candel against oxidative damage (Takemura et al., 2000). In photosynthetic organisms plasma cell membranes are the primary target of heavy metal action that cause lipid peroxidation via ROS production (Chen et al., 2012; Dingjan et al., 2016; Anjum et al., 2017). Enhanced lipoxygenase activity causes lipid peroxidation through the formation of oxylipins (Porta and Rocha-Sosa, 2002; Alemayehu et al., 2013). 
Lipoxygenase play a significant role in heavy metal induced oxidative stress in Arabidopsis thaliana and Lessonia nigrescens (Vanhoudt et al., 2011). Singh and Agrawal (2009) studied the biochemical response of Abelmoschus esculentus plants grown in different application rates of sewage sludge. The results showed a significant increase of 27 and $89 \%$ in chlorophyll content of plants grown in 20 and $40 \%$ sewage sludge amendments (SSA) respectively at 40 days after sowing (DAS), however, it was decreased by $10 \%(20 \%$ SSA) and $47 \%(40 \%$ SSA $)$ at 60 DAS. Accumulation of heavy metals in plants at later stages of growth might have been the reason behind the decrease of chlorophyll content. Similarly, a reduction in photosynthetic rate, increased level of phenol, peroxide, and ascorbic acid content was noticed with increasing level of sewage sludge application, suggesting a defensive response against heavy metal induced oxidative stress experienced by the plants. Similar results were observed in A. esculentus (Singh and Agrawal, 2009), Vigna radiata (Singh and Agrawal, 2010a), and Oryza sativa (Singh and Agrawal, 2010b). Chen et al. (2003) observed the effect of $\mathrm{Cd}$ on the physiology of carrot and radish plant roots grown under different concentrations/ levels of $\mathrm{Cd}$. The results indicate a significant decrease in germination and root growth of both the plants at and above $20 \mathrm{mg} / \mathrm{l}$ of Cd. Similarly, the activities of superoxide dismutase (SOD), catalase (CAT), polyphenol oxidase (PPO), and peroxidase (POX) were decreased significantly with increasing $\mathrm{Cd}$ concentration. Also, proline concentration increased at $20 \mathrm{mg} / \mathrm{l}$ of Cd and decreased further with increasing $\mathrm{Cd}$ concentration.

Thounaojam et al. (2012) examined the effect of $\mathrm{Cu}$ on rice plants (O. sativa. L. var. MSE-9). Plants readily absorbed the $\mathrm{Cu}$ though maximum accumulation was noticed in the root than shoot system. Also, $\mathrm{H}_{2} \mathrm{O}_{2}$ and malondialdehyde (MDA) content were increased significantly with the elevated $\mathrm{Cu}$ concentration inducing oxidative stress. The level of antioxidative enzymes like APX, GPX, SOD, GR, ascorbic acid (ASH), and GSH was increased significantly, however CAT did not show statistically significant changes. The results suggested that excess $\mathrm{Cu}$ induced oxidative stress by ROS production, however, the plant's antioxidative system scavenged the deleterious effect of excess $\mathrm{Cu}$ in an active manner.

Similarly, Li et al. (2013) studied the antioxidative response and proline metabolism in roots and seeds of wheat plants under different doses of $\mathrm{Zn}(0.5,1$, and $3 \mathrm{mM})$. The highest dose of $\mathrm{Zn}$ caused significant reduction in total chlorophyll (chl) and chl a, while chl b content decreased under all doses. $\mathrm{H}_{2} \mathrm{O}_{2}$ and malondialdehyde (MDA) level were increased significantly in comparison with control. Likewise, APX, CAT, GR, POX activities were improved significantly.

\section{PLANT-SOIL INTERACTION AND DYNAMICS/TRANSLOCATION OF HEAVY METALS}

The present section deals with several aspects of phytoremediation including uptake of metal ion from soil, translocation, and mechanisms of HM hypertolerance in plants
(Figure 1). To enhance the bio-availability of metal ions, plants use various strategies. For instance, rhizosphere acidification, carboxylate formation, and secretion of phytosiderophores so as to assist the solubilization and chelation of metal ions (Rajkumar et al., 2010; O’Brien et al., 2014). Another important role in managing the accessibility of metal ions to plant roots is played by soil micro-organisms in the rhizosphere as well as the enzymes secreted by them (Burns and Dick, 2002). The portion of metal ions that can translocate and get absorbed by the plants is called the bioavailable portion. Therefore, it is very crucial to identify the bioavailable portion of the total heavy metals in the soil for successful reclamation of polluted soil (Olaniran et al., 2013). There are two processes that facilitate the uptake of metal ions into roots, one is passive diffusion from the cell membrane and the other is active transport against concentration or electrochemical potential gradients intervened by carriers. These carriers may be complexing agents, like proteins or organic acids that react with metal ions (Fergusson, 1990).

Generally, metal ions penetrate root cells through two available pathways: apoplastic and symplastic. The former is feasible in only as non-cationic metal chelates, as increased cation exchange capacity is exhibited by the cell wall (Raskin et al., 1997). Therefore, immobilization in apoplastic and symplastic compartments is achieved by forming phosphates, sulfates, or carbonate precipitates, because many of the metal/metalloid cannot translocate themselves in vascular system (Garbisu and Alkorta, 2001). For symplastic movement metal ions must traverse through the plasma membrane. The internal movement of metal ions is facilitated by electrochemical gradients produced due to the high negative resting potential of the plasma membrane (Raskin et al., 1994). Also, through stele the bioaccumulated metal ions in the vacuoles may penetrate xylem tissue. Therefore, the penetration of metals into the xylem through root is decided by three processes: (i) metal ion sequestration into root cells; (ii) symplasmic transport in the stele; and (iii) release into the xylem (Saxena and Misra, 2010).

For instance, it has been reported that under Al-stress, the roots of buckwheat secret oxalic acid to form non-toxic Aloxalate complexes which gets transferred into the leaves (Ma et al., 1998; Hall, 2002). Likewise, several fern species have been examined for their As accumulation potential in their fronds. Ma et al. (2001) was the first to identify the ability of Chinese brake fern (Pteris vittata) to hyper-accumulate As (more than $1,000 \mathrm{mg}$ As/ $\mathrm{kg}$ shoot dry weight, DW). This plant has the capacity to transform As (V) to As (III) and transports it via xylem as an As (III)-S compound along with water and minerals, and gets accumulated in the fronds as As (III). Likewise, Wang et al. (2002) also investigated that $P$. vittata, when introduced to high doses of As in hydroponic media, has the capability to hyper-accumulate up to $27,000 \mathrm{mg} \mathrm{kg}^{-1} \mathrm{DW}$ of As. Few other plant species like A. thaliana and Brassica juncea also reduce As (V) but have lower capacity than $P$. vittata (Singh and $\mathrm{Ma}, 2006)$. Additionally, the improper removal of Cd waste has caused emission problems in densely populated regions of the world (Järup, 2003). The plasma membrane of the root cells is characterized by electrochemical potential gradient that forces 
Cd or other ions in the root cells (Blaylock and Huang, 2000). Though, the concentration of $\mathrm{Fe}$ ion inhibits the uptake of $\mathrm{Cd}$. For example, Fe concentrations of $0-10 \mu \mathrm{M}$ inhibit $\mathrm{Cd}$ uptake in Hordeum vulgare (barley) (Sharma et al., 2004). Conversely, in Thlaspi caerulescens Ganges ecotype, the expression of encoding genes for $\mathrm{Fe}$ (II) gets upregulated by the deficiency in Fe that supports the uptake of Cd (Lombi et al., 2002). Furthermore, in Arabidopsis halleri, the translocation of Cd into the xylem of roots is partly shared with Fe and/or $\mathrm{Zn}$ transport (Ueno et al., 2008). However, in maize plants (Zea mays), phytosiderophore 2-deoxymugineic acid (DMA) is discharged due to introduction of $\mathrm{Cd}$ under Fe deficit conditions and chelates $\mathrm{Cd}$. The uptake of Fe and Cd is facilitated by this weak complex. Transmission of toxic metal from soil to plant and then ultimately to humans has been poorly examined. Evidence shows that mostly end consumers are at risk when agricultural production contains excessive toxic metals. However, with the advancement in phytoremediation studies and genetic modification of plants to enhance their bio-accumulation capacity, the possibility of undesired danger of metal contamination through bioaccumulation in plants has increased. For this reason, risk assessment analysis must be incorporated in phytoremediation projects along with precautions to minimize the transfer of toxic metals to higher trophic level.

Plants have to continuously deal with abiotic and biotic stress. However, a few plants (hyperaccumulator) function extremely well under high ROS generation due to heavy metal stress. To counter oxidative damage the plants have derived an array of defense mechanisms to abort cell injury and tissue dysfunction (Benekos et al., 2010; Ruan et al., 2011) which operate indivdually or together in plants. The capability of plant defense mechanisms depends upon plant species, plant maturity and the continuation and degree of exposure. Specific plant parts are involved in heavy metal sequestration or detoxification, like trichomes (Küpper et al., 2000), epidermis (Freeman et al., 2006), cuticle (Robinson et al., 2003), and if not detoxified causes disruption of the photosynthetic apparatus. Furthermore, plant root cells are the main centers for sequestering heavy metals absorbed by the plants.

Root cells detoxify heavy metal by making complexes with amino acids, organic acids, or in vacuoles (Rascio and NavariIzzo, 2011). These complexes check the mobility of heavy metal and consequently help in leaf tissue protection along with metabolically dynamic photosynthetic cells from heavy metal injury (Rascio and Navari-Izzo, 2011). When plants are subjected to increased concentration of heavy metal then toxicity can only be minimized through strong defense mechanisms and adequate sinks for accumulating toxic metals (Wojas et al., 2010; Hassan and Aarts, 2011; Ali et al., 2013; Sharma et al., 2016). If plants comprise these sinks, they can remove the deleterious effects of these metals. Plant metal homeostasis and metal detoxification occur mainly during vacuolar sequestration (Ali et al., 2013; Sharma et al., 2016). Various pathways have been adopted during metal sequestration in vacuoles. Metal homeostasis in plants is operated by a range of families of transporters identified by genome sequencing (Klatte et al., 2009). These families of transporters are heavy metal ATPases (HMAs),
ATP-binding cassettes (ABC), Zrt/Irt-like protein (ZIP), cation exchangers (CAXs), cation diffusion facilitators (CDF), and natural resistance-associated macrophage (NRAMP) (Hall and Williams, 2003; Grotz and Guerinot, 2006; Ovečka and Takác, 2014; Thakur et al., 2016). Amongst these transporters, NRAMP, $\mathrm{CDF}$, and $\mathrm{ABC}$ have been recognized as decisive for heavy metal tolerance (Hanikenne et al., 2005; Chaffai and Koyama, 2011; Ovečka and Takác, 2014). Moreover, Phytochelatins (PCs) and metallothioneins (MTs) are the most vital metal-binding ligands found in plant cells (Rea, 2012; Ovečka and Takác, 2014; Inouhe et al., 2015). Phytochelatins are tiny HM binding polypeptides having structure of ( $\gamma$-Glu-Cys)nGly $(n=2-11)$. Phytochelatins fits in various classes of cysteine-rich HM-binding protein molecules. Heavy metals activate phytochelatin synthase (PCS), further stimulating PCs (Jiang and Liu, 2010; Ovečka and Takác, 2014). Metal ions such as $\mathrm{Pb}, \mathrm{Cd}, \mathrm{Cu}$, and $\mathrm{Zn}$ activates the synthesis of PCs which gets catalyzed non-translationally by phytochelatin synthase (Ogawa et al., 2011; Ovečka and Takác, 2014). These natural chelators in plants bind and translocate heavy metals toward cell vacuole (Israr et al., 2011; Inouhe et al., 2015). It is presumed that the translocation of metal-PC complex is assisted by ABC transporters (Prévéral et al., 2009). Usually, in cytosol PCs binds heavy metal and this resultant complex is sequestered in vacuoles (Ogawa et al., 2011; Sharma et al., 2016). As a result, concentration of free metal ions are reduced in the cytosol. In such a way, ROS generation gets inhibited by natural ligands which are the outcome of HM interaction with redox system of the plant.

A sulfur containing tri-peptide, glutathione (GSH; $\gamma$ glutamatecysteine-glycine) is amongst the most significant low molecular weight biological thiols. Glutathione defends plants against metal toxicity by extinguishing metal-induced ROS (Noctor et al., 2012; Viehweger, 2014). A series of ROS react non-enzymatically with glutathione and the resultant formation is thiyl radicals (Mahmood et al., 2016). These radicals might produce $\mathrm{O}_{2}^{\bullet-}$, which gets counter balanced by SOD/CAT enzymes. It is noteworthy that GSH also reacts with LPO (lipid peroxidation) metabolite 4-hydroxy-2-nonenal (Wonisch et al., 1997), and exhibit a major role in the preliminary resistance against malondialdehyde (a highly lethal LPO product) (Turton et al., 1997). Elevated level of proline accumulation in heavily HM stressed plants is documented in several reports, which is due to glutathione production, which is also in correlation with less damage to plant protein and membranes (Liu et al., 2009). Likewise, thiol group of cysteine is tremendously susceptible to ROS because of its hypersensitivity toward oxidation. Another tolerance mechanism that has been developed by plants in order to protect proteins from oxidation is glutathionylation, whose outcome is reversible post-translational alteration of protein thiols (Michelet et al., 2006; Zaffagnini et al., 2012; Asgher et al., 2017). Additionally, plants have another mechanism to detoxify any free radical which is achieved by triggering antioxidant enzymes such as CAT, GR, APX, POD, SOD, dehydroascorbate reductase (DHAR), and monodehydroascorbate reductase (MDHAR) (Vanhoudt et al., 2011; Cestone et al., 2012; Shahid et al., 2014; Nahar et al., 2016; Rajewska et al., 2016). Previously, many researchers have proved 
that elevated level of antioxidant enzymes can boost stress tolerance. The antioxidant enzymes get triggered in various plant parts in order to scavenge the ROS species which are generated during HM toxicity ( $\mathrm{He}$ et al., 2011; Cestone et al., 2012; Shahid et al., 2014). In addition to this, the bacteria that can produce siderophores, 1-aminocyclopropane-1-carboxylate (AAC) deaminase and auxin (IAA) play a significant role in plant growth promotion, lowering the level of ethylene by cleaving AAC (precursor of ethylene that level increase in the presence of heavy metal) to ammonia and $\alpha$ - ketobutyrate, and in supplying iron to the plants for optimal growth (Wang et al., 2000; Glick, 2014). Siderophores are small organic molecules produced by microorganisms under iron limiting environment which promote the uptake of iron to the microorganisms (Saha et al., 2016). Though, the main role of siderophores is the chelation of ferric ion, but they also play a significant role in neutralizing toxic metals such as $\mathrm{Cr}, \mathrm{Cu}, \mathrm{Al}$, and $\mathrm{Pb}$ in contaminated soil (Rajkumar et al., 2010; O'Brien et al., 2014). The mobility of siderophore bound heavy metals other than iron in the cell is not efficient while iron moves into the cells efficiently (Braud et al., 2009; Noinaj et al., 2010). For example, siderophore producing Pseudomonas azotoformans helps in removing As from contaminated sites (Nair et al., 2007). Likewise, siderophores also play an important role in mobilizing metals from mine waste (Edberg et al., 2010). Therefore, siderophores could be used as bioremediating agent for metals.

Heavy metals usually have low mobility in the soil and therefore are not easily absorbed by the plant roots. Thus, the interaction between plant roots and soil microbes could improve the bioavailability of heavy metals in rhizosphere (Saravanan et al., 2007; Sheng et al., 2008). Although, there are many literatures available for soil-bacteria assisted phytoremediation but our knowledge about potential of endophytic bacteria in phytoremediation of heavy- metal contaminated soils is still in their infancy (Sheng et al., 2008). Li et al. (2012) tested an endophytic fungus in rice (O. sativa L.) subjected to different concentration of lead $(\mathrm{Pb})$ stress. The results showed significantly higher chlorophyll and carotenoid content in the endophyte infected seedlings compared to non-infected seedlings. Likewise, net photosynthetic rate, transpiration rate, and water use efficiency were significantly higher in endophyte infected seedlings compared to non-infected seedlings under higher concentrations of $\mathrm{Pb}$.

\section{CONCLUDING REMARKS AND FUTURE PERSPECTIVE}

Heavy metal pollution poses serious environmental threat on a global scale. When plants are introduced to the elevated toxic level of heavy metal/ metalloid they demonstrate significantly reduced growth accompanied with poor productivity and yields. Heavy metal pollution destroys plants' cellular structures and membranes due to elevated ROS species production. ROS species also inhibit basic metabolism of plants and transport processes within the plant. However, abiotic stresses (like drought and salinity) can also cause these adverse effects. But, plants combating heavy metal stress have some exceptional features. Plants alleviate the effects of heavy metal toxicity by limiting the uptake of metal/metalloids ions, complexing and chelating them either in extracellular space or in the cytoplasm, and possibly sequestration in the vacuole. To achieve this, the plant must be proficient enough to trigger defense responses like activation and expression of antioxidative enzymes. In addition to this, plants must regulate their mechanisms for averting or fixing secondary defects produced during oxidative stress. However, diverse plant species develop different strategies to combat the problem of heavy metal toxicity. Increased uptake of metal ions by plants also demonstrates elevated level of metals in the soil (esp. metals which are mobile). Beyond a certain critical concentrations of heavy metals, plants' yield and quality are severely affected which can influence animal and human health. Careful monitoring is required to evaluate the concentrations of toxic heavy metals in plants as they may potentially reach the danger level in animal or human being via the food chain without having any deleterious effect on plants. Heavy metals are frequently associated with other major nutrients that have synergistic, additive, or antagonistic effects. Hence, the sustenance and vigor of our future generation requires that the soil resources must be preserved from slow and insidious poisoning of heavy metals. This proves to be the biggest challenge for our scientific investigators, advisors, and legislators. Another important challenge to be faced by the scientist is a long-term prediction of possible hazards in soils arising from different soil conditions. Therefore, scientists from all over the globe can and should continue to cooperate in investigations and development of stringent guidelines for disposal and use of toxic metals in agricultural soil.

\section{AUTHOR CONTRIBUTIONS}

RS, VS, and AS proposed and structured the review. VS, AS, and PS wrote the manuscript. AS made the figure. SS and AdA reviewed and improved English of the manuscript. All the authors participated in discussion of the research.

\section{ACKNOWLEDGMENTS}

Authors are thankful to the Director, Dean, and Head, Institute of Environment and Sustainable Development, Banaras Hindu University for providing the necessary facilities. RS is thankful to Department of Science and Technology, India, University of Nebraska-Lincoln, Indo-US Science and Technology Forum (IUSSTF) and Robert Daugherty Water for Food Institute (DWFI)-University of Nebraska for support. AS is thankful to the HoD, Department of Botany, University of Gour Banga, for this collaborative work. The authors extend their sincere thanks to Dr. Shannon L. Bartelt-Hunt, Department of Civil Engineering, University of Nebraska-Lincoln, USA for improving the English and grammar of the manuscript. 


\section{REFERENCES}

Abdu, N., Agbenin, J. O., and Buerkert, A. (2011). Geochemical assessment, distribution and dynamics of trace metals in urban agricultural soils under long-term wastewater irrigation in Kano, northern Nigeria. J. Plant Nutr. Soil Sci. 173, 447-458. doi: 10.1002/jpln.201000333

Agrawal, G. K., Tamogami, S., Iwahashi, H., Agrawal, V. P., and Rakwal, R. (2003). Transient regulation of jasmonic acid-inducible rice MAP kinase gene (OsBWMK1) by diverse biotic and abiotic stresses. Plant Physiol. Biochem. 41, 355-361. doi: 10.1016/S0981-9428(03)00030-5

Ahmed, M. J. K., and Ahmaruzzaman, M. (2016). A review on potential usage of industrial waste materials for binding heavy metal ions from aqueous solutions. J. Water Process. Eng. 10, 39-47. doi: 10.1016/j.jwpe.2016.01.014

Alemayehu, A., Bocová, B., Zelinová, V., Mistrík, I., and Tamás, L. (2013). Enhanced lipoxygenase activity is involved in barley root tip swelling induced by cadmium, auxin or hydrogen peroxide. Environ. Exp. Bot. 93, 55-62. doi: 10.1016/j.envexpbot.2013.06.004

Ali, H., Khan, E., and Sajad, M. A. (2013). Phytoremediation of heavy metals-concepts and applications. Chemosphere 91, 869-881. doi: 10.1016/j.chemosphere.2013.01.075

Alloway, B. J. (ed.). (2013). "Sources of heavy metals and metalloids in soils," in Heavy Metals in Soils (Dordrecht: Springer Netherlands), 11-50.

Alves, L. R., Monteiro, C. C., Carvalho, R. F., Ribeiro, P. C., Tezotto, T., Azevedo, R. A., et al. (2017). Cadmium stress related to root-to-shoot communication depends on ethylene and auxin in tomato plants. Environ. Exp. Bot. 134, 102-115. doi: 10.1016/j.envexpbot.2016.11.008

Anjum, S. A., Ashraf, U., Imran, K. H. A. N., Tanveer, M., Shahid, M., Shakoor, A., et al. (2017). Phyto-toxicity of chromium in maize: oxidative damage, osmolyte accumulation, anti-oxidative defense and chromium uptake. Pedosphere 27, 262-273. doi: 10.1016/S1002-0160(17)60315-1

Aoyama, M., and Itaya, S. (1995). Effects of copper on the metabolism of 14Clabeled glucose in soil in relation to amendment with organic materials. Soil Sci. Plant Nutr. 41, 245-252. doi: 10.1080/00380768.1995.10419581

Araújo, A. S. F., de Melo, W. J., and Singh, R. P. (2010). Municipal solid waste compost amendment in agricultural soil: changes in soil microbial biomass.Rev. Environ. Sci. Biotechnol. 9, 41-49. doi: 10.1007/s11157-009-9179-6

Arya, S. K., and Mukherjee, A. (2014). Sensitivity of Allium cepa and Vicia faba towards cadmium toxicity. J. Soil Sci. Plant Nutr. 14, 447-458. doi: $10.4067 /$ S0718-95162014005000035

Arya, S. K., Basu, A., and Mukherjee, A. (2013). Lead induced genotoxicity and cytotoxicity in root cells of Allium cepa and Vicia faba. Nucleus 56, 183-189. doi: 10.1007/s13237-013-0099-z

Aryal, R., Beecham, S., Sarkar, B., Chong, M. N., Kinsela, A., Kandasamy, J., et al. (2017). Readily wash-off road dust and associated heavy metals on motorways. Water Air Soil Pollut. 228:1. doi: 10.1007/s11270-016-3178-3

Asgher, M., Per, T. S., Anjum, S., Khan, M. I. R., Masood, A., Verma, S., et al. (2017). "Contribution of glutathione in heavy metal stress tolerance in plants", in Reactive Oxygen Species and Antioxidant Systems in Plants: Role and Regulation under Abiotic Stress, eds M. I. R. Khan and N. A. Khan (Singapore: Springer Nature Singapore Pte. Ltd.), 297-313.

Aslam, R., Bhat, T. M., Choudhary, S., and Ansari, M. Y. K. (2017). An overview on genotoxicity of heavy metal in a spice crop (Capsicum annuum L.) in respect to cyto-morphological behaviour. Caryologia 70, 42-47. doi: $10.1080 / 00087114.2016 .1258884$

Atafar, Z., Mesdaghinia, A., Nouri, J., Homaee, M., Yunesian, M., Ahmadimoghaddam, M., et al. (2010). Effect of fertilizer application on soil heavy metal concentration. Environ. Monit. Assess. 160, 83-89. doi: 10.1007/s10661-008-0659-x

Awasthi, S. K. (1998). Prevention of Food Adulteration Act No 37 of 1954. Central and State Rules as Amended for 1999. Ashoka Law House.

Bal, W., and Kasprzak, K. S. (2002). Induction of oxidative DNA damage by carcinogenic metals. Toxicol. Lett. 127, 55-62. doi: $10.1016 /$ S0378-4274(01)00483-0

Balkhair, K. S., and Ashraf, M. A. (2016). Field accumulation risks of heavy metals in soil and vegetable crop irrigated with sewage water in western region of Saudi Arabia. Saudi J. Biol. Sci. 23, S32-S44. doi: 10.1016/j.sjbs.2015.09.023

Barbosa, J. S., Cabral, T. M., Ferreira, D. N., Agnez-Lima, L. F., and De Medeiros, S. B. (2010). Genotoxicity assessment in aquatic environment impacted by the presence of heavy metals. Ecotoxicol. Environ.Saf. 73, 320-325. doi: 10.1016/j.ecoenv.2009.10.008

Benekos, K., Kissoudis, C., Nianiou-Obeidat, I., Labrou, N., Madesis, P., Kalamaki, M., et al. (2010). Overexpression of a specific soybean GmGSTU4 isoenzyme improves diphenyl ether and chloroacetanilide herbicide tolerance of transgenic tobacco plants. J. Biotechnol. 150, 195-201. doi: 10.1016/j.jbiotec.2010.07.011

Bewley, R. J. F., and Stotzky, G. (1983). Effects of cadmium and zinc on microbialactivity in soil; influence of clay minerals. Part I. Metals added individually. Sci. Tot. Environ. 31, 41-55. doi: 10.1016/0048-9697(83)90055-4

Blaylock, M. J., and Huang, J. W. (2000). "Phytoextraction of metals," in Phytoremediation of Toxic Metals: Using Plants to Clean up the Environment, eds I. Raskin and B. D. Ensley (New York, NY: John Wiley and Sons), 53-70.

Braud, A., Hoegy, F., Jezequel, K., Lebeau, T., and Schalk, I. J. (2009). New insights into the metal specificity of the Pseudomonas aeruginosa pyoverdine-iron uptake pathway. Environ. Microbiol. 11, 1079-1091. doi: 10.1111/j.1462-2920.2008.01838.x

Bringmark, L., and Bringmark, E. (2001). Lowest effect levels of lead and mercury on decomposition of mor layer samples in a long-term experiment. Water Air Soil Pollut. Focus 1, 425-437. doi: 10.1023/A:1017530321614

Brookes, P. C., and McGrath, S. P. (1984). Effect of metal toxicity on the size of the soil microbial biomass. Eur. J. Soil Sci. 35, 341-346. doi: 10.1111/j.1365-2389.1984.tb00288.x

Brookes, P. C., McGrath, S. P., and Heijnen, C. (1986). Metal residues in soils previously treated with sewage-sludge and their effects on growth and nitrogen fixation by blue-green algae. Soil Biol. Biochem. 18, 345-353. doi: 10.1016/0038-0717(86)90037-4

Burges, A., Epelde, L., and Garbisu, C. (2015). Impact of repeated single-metal and multi-metal pollution events on soil quality. Chemosphere 120, 8-15. doi: 10.1016/j.chemosphere.2014.05.037

Burns, R. G., and Dick, R. P. (Eds.) (2002). Enzymes in the Environment: Activity, Ecology, and Applications. New York, NY: Marcel Dekker.

Carlisle, D. M., and Clements, W. H. (2005). Leaf litter breakdown, microbial respiration and shredder production in metal-polluted streams. Freshw. Biol. 50, 380-390. doi: 10.1111/j.1365-2427.2004.01323.x

Carnelo, L. G. L., de Miguez, S. R., and Marbán, L. (1997). Heavy metals input with phosphate fertilizers used in Argentina. Sci. Tot. Environ. 204, 245-250. doi: 10.1016/S0048-9697(97)00187-3

Carrasco-Gil, S., Estebaranz-Yubero, M., Medel-Cuesta, D., Millán, R., and Hernández, L. E. (2012). Influence of nitrate fertilization on Hg uptake and oxidative stress parameters in alfalfa plants cultivated in a $\mathrm{Hg}$ polluted soil. Environ. Exp. Bot. 75,16-24. doi: 10.1016/j.envexpbot.2011. 08.013

Cestone, B., Cuypers, A., Vangronsveld, J., Sgherri, C., and Navari-Izzo, F. (2012). The influence of EDDS on the metabolic and transcriptional responses induced by copper in hydroponically grown Brassica carinata seedlings. Plant Physiol. Biochem. 55:43-51. doi: 10.1016/j.plaphy.2012.03.011

Chaffai, R., and Koyama, H. (2011). Heavy metal tolerance in Arabidopsis thaliana. Adv. Bot. Res. 60, 1-49. doi: 10.1016/B978-0-12-385851-1.00001-9

Chakravarty, B., and Srivastava, S. (1992). Toxicity of some heavy metals in vivo and in vitro in Helianthus annuus. Mutat. Res. 283, 287-294. doi: 10.1016/0165-7992(92)90061-L

Chaperon, S., and Sauve, S. (2007). Toxicity interaction of metals (Ag, Cu, Hg, $\mathrm{Zn}$ ) to urease and dehydrogenase activities in soils. Soil Biol. Biochem. 39, 2329-2338. doi: 10.1016/j.soilbio.2007.04.004

Chauhan, P. S., Singh, A., Singh, R. P., and Ibrahim, M. H. (2012). "Environmental impacts of Organic fertilizer usage in agriculture," in Organic Fertilizers: Types, Production and Environmental Impact, ed R. P. Singh (Hauppauge, NY: Nova Science Publisher), 63-84.

Chen, B., Stein, A. F., Maldonado, P. G., de la Campa, A. M. S., GonzalezCastanedo, Y., Castell, N., et al. (2013). Size distribution and concentrations of heavy metals in atmospheric aerosols originating from industrial emissions as predicted by the HYSPLIT model. Atmos. Environ. 71, 234-244. doi: 10.1016/j.atmosenv.2013.02.013

Chen, J., He, F., Zhang, X., Sun, X., Zheng, J., and Zheng, J. (2014). Heavy metal pollution decreases microbial abundance, diversity and activity within particle-size fractions of a paddy soil. FEMS Microbiol. Ecol. 87, 164-181. doi: $10.1111 / 1574-6941.12212$ 
Chen, L., Hu, J. Y., and Wang, S. Q. (2012). The role of antioxidants in photoprotection: a critical review. J. Am. Acad. Dermatol. 67, 1013-1024. doi: 10.1016/j.jaad.2012.02.009

Chen, Y. X., He, Y. F., Luo, Y. M., Yu, Y. L., Lin, Q., and Wong, M. H. (2003). Physiological mechanism of plant roots exposed to cadmium. Chemosphere 50, 789-793. doi: 10.1016/S0045-6535(02)00220-5

Cheng, H., and $\mathrm{Hu}, \mathrm{Y} .(2010)$. Lead $(\mathrm{Pb})$ isotopic fingerprinting and its applications in lead pollution studies in China: a review. Environ. Pollut. 158, 1134-1146. doi: 10.1016/j.envpol.2009.12.028

Circu, M. L., and Aw, T. Y. (2010). Reactive oxygen species, cellular redox systems, and apoptosis. Free Radic. Biol. Med. 48, 749-762. doi: 10.1016/j.freeradbiomed.2009.12.022

Clemens, S., and Ma, J. F. (2016). Toxic heavy metal and metalloid accumulation in crop plants and foods. Annu. Rev. Plant Biol. 67, 489-512. doi: 10.1146/annurev-arplant-043015-112301

Crecchio, C., Curci, M., Pizzigallo, M. D., Ricciuti, P., and Ruggiero, P. (2004). Effects of municipal solid waste compost amendments on soil enzyme activities and bacterial genetic diversity. Soil Biol. Biochem. 36, 1595-1605. doi: 10.1016/j.soilbio.2004.07.016

Cunningham, R. P. (1997). DNA repair: caretakers of the genome? Curr. Biol. 7, 576-579. doi: 10.1016/S0960-9822(06)00286-7

Cuypers, A., Karen, S., Jos, R., Kelly, O., Els, K., Tony, R., et al. (2011). The cellular redox state as a modulator in cadmium and copper responses in Arabidopsis thaliana seedlings. J. Plant Physiol. 168, 309-316 doi: 10.1016/j.jplph.2010.07.010

Cuypers, A., Remans, T., Weyens, N., Colpaert, J., Vassilev, A., and Vangronsveld, J. (2013). "Soil-plant relationships of heavy metals and metalloids," in Heavy Metals in Soils:Trace Metals and Metalloids in Soils and Their Bioavailability, ed B. J. Alloway (Dordrecht: Springer Netherlands), 161-193.

Dai, J., Becquer, T., Rouiller, J. H., Reversat, G., Bernhard-Reversat, F., and Lavelle, P. (2004). Influence of heavy metals on $\mathrm{C}$ and $\mathrm{N}$ mineralisation and microbial biomass in $\mathrm{Zn-}, \mathrm{Pb}-, \mathrm{Cu}-$, and $\mathrm{Cd}$-contaminated soils. Appl. Soil Ecol. 25, 99-109. doi: 10.1016/j.apsoil.2003.09.003

Dar, G. H., and Mishra, M. M. (1994). Influence of cadmium on carbon and nitrogen mineralization in sewage sludge amended soils. Environ. Pollut. 84, 285-290. doi: 10.1016/0269-7491(94)90140-6

D'Autréaux, B., and Toledano, M. B. (2007). ROS as signalling molecules: mechanisms that generate specificity in ROS homeostasis. Nat. Rev. Mol. Cell Biol. 8, 813-824. doi: 10.1038/nrm2256

De Catanzaro, J. B., and Hutchinson, T. C. (1985). Effects of nickel addition on nitrogen mineralization, nitrification, and nitrogen leaching in some boreal forest soils. Water Air Soil Pollut. 24, 153-164.

de Quadros, P. D., Zhalnina, K., Davis-Richardson, A. G., Drew, J. C., Menezes, F. B., Flávio, A. D. O., et al. (2016). Coal mining practices reduce the microbial biomass, richness and diversity of soil. Appl. Soil Ecol. 98, 195-203. doi: 10.1016/j.apsoil.2015.10.016

Dembitsky, V. M., and Rezanka, T. (2003). Natural occurrence of arseno compounds in plants, lichens, fungi, algal species, and microorganisms. Plant Sci. 165, 1177-1192. doi: 10.1016/j.plantsci.2003.08.007

Deng, W., Li, X., An, Z., and Yang, L. (2016). The occurrence and sources of heavy metal contamination in peri-urban and smelting contaminated sites in Baoji, China. Environ. Monit. Assess. 188:251. doi: 10.1007/s10661-0165246-y

Dezhban, A., Shirvany, A., Attarod, P., Delshad, M., Matinizadeh, M., and Khoshnevis, M. (2015). Cadmium and lead effects on chlorophyll fluorescence, chlorophyll pigments and proline of Robinia pseudoacacia. J. For. Res. 26, 323-329. doi: 10.1007/s11676-015-0045-9

Dingjan, I., Verboogen, D. R., Paardekooper, L. M., Revelo, N. H., Sittig, S. P., Visser, L. J., et al. (2016). Lipid peroxidation causes endosomal antigen release for cross-presentation. Sci. Rep. 6:22064. doi: 10.1038/srep22064

dos Santos, J. V., Varón-López, M., Soares, C. R. F. S., Leal, P. L., Siqueira, J. O., and de Souza Moreira, F. M. (2016). Biological attributes of rehabilitated soils contaminated with heavy metals. Environ. Sci. Pollut. Res. 23, 6735-6748. doi: 10.1007/s11356-015-5904-6

Dotaniya, M. L., Rajendiran, S., Meena, V. D., Saha, J. K., Coumar, M. V., Kundu, S., et al. (2017). Influence of chromium contamination on carbon mineralization and enzymatic activities in Vertisol. Agric. Res. 6, 91-96. doi: $10.1007 / \mathrm{s} 40003-016-0242-6$
Duarte, S., Pascoal, C., Alves, A., Correia, A., and Cassio, F. (2008). Copper and zinc mixtures induce shifts in microbial communities and reduce leaf litter decomposition in streams. Freshw. Biol. 53, 91-101. doi: 10.1111/j.1365-2427.2007.01869.x

Dubey, B., Pal, A. K., and Singh, G. (2017). "Airborne particulate matter: source scenario and their impact on human health and environment," in Environmental Issues Surrounding Human Overpopulation, eds R. P. Singh, A. Singh, and V. Srivastava (Hershey, PA: IGI Global), 202-223.

Duruibe, J. O., Ogwuegbu, M. O. C., and Egwurugwu, J. N. (2007). Heavy metal pollution and human biotoxic effects. IJPS 2, 112-118.

Edberg, F., Kalinowski, B. E., Holmström, S. J., and Holm, K. (2010). Mobilization of metals from uranium mine waste: the role of pyoverdines produced by Pseudomonas fluorescens. Geobiology 8, 278-292. doi: 10.1111/j.1472-4669.2010.00241.x

European Union, EU (2002). Heavy Metals in Wastes, European Commission on Environment. Available online at: http://www.ec.europa.eu/environment/ waste/studies/pdf/heavymetalsreport.pdf

Fergusson, J. E. (1990). The Heavy Metals: Chemistry, Environmental Impact and Health Effects. Oxford: Pergamon Press, 382-388.

Ferreira, V., Koricheva, J., Duarte, S., Niyogi, D. K., and Guérold, F. (2016). Effects of anthropogenic heavy metal contamination on litter decomposition in streams-a meta-analysis. Environ. Pollut. 210, 261-270. doi: 10.1016/j.envpol.2015.12.060

Fishel, F. M. (2014). Pesticide Toxicity Profile: Copper-based Pesticides. University of Florida, 5.

Fortini, P., Pascucci, B., Parlanti, E., D'errico, M., Simonelli, V., and Dogliotti, E. (2003). 8-Oxoguanine DNA damage: at the crossroad of alternative repair pathways. Mutat. Res. Fund. Mol. Mech. Mut. 531, 127-139. doi: 10.1016/j.mrfmmm.2003.07.004

Foyer, C. H., and Noctor, G. (2005). Redox homeostasis and antioxidant signalling: a metabolic interface between stress perception and physiological responses. Plant Cell 17, 1866-1875. doi: 10.1105/tpc.105.033589

Franco-Uría, A., López-Mateo, C., Roca, E., and Fernández-Marcos, M. L. (2009). Source identification of heavy metals in pastureland by multivariate analysis in NW Spain. J. Haz. Mater. 165, 1008-1015. doi: 10.1016/j.jhazmat.2008.10.118

Freedman, B., and Hutchinson, T. C. (1980). Effects of smelter pollutants on forest leaf litter decomposition near a nickel-copper smelter at Sudbury, Ontario. Can. J. Bot. 58, 1722-1736. doi: 10.1139/b80-200

Freeman, J. L., Quinn, C. F., Marcus, M. A., Fakra, S., and Pilon-Smits, E. A. (2006). Selenium-tolerant diamondback moth disarms hyperaccumulator plant defense. Curr. Biol. 16, 2181-2192. doi: 10.1016/j.cub.2006.09.015

Garbisu, C., and Alkorta, I. (2001). Phytoextraction: a costeffective plant-based technology for the removal of metals from the environment. Bioresour. Technol. 77, 229-236. doi: 10.1016/S0960-8524(00)00108-5

Garcia-Gil, J. C., Plaza, C., Soler-Rovira, P., and Polo, A. (2000). Longterm effects of municipal solid waste compost application on soil enzyme activities and microbial biomass. Soil Biol. Biochem. 32, 1907-1913. doi: 10.1016/S0038-0717(00)00165-6

Gastaldo, J., Viau, M., Bouchot, M., Joubert, A., Charvet, A. M., and Foray, N. (2008). Induction and repair rate of DNA damage: a unified model for describing effects of external and internal irradiation and contamination with heavy metals. J.Theor. Biol. 251, 68-81. doi: 10.1016/j.jtbi.2007.10.034

Gichner, T., Patková, Z., Száková, J., and Demnerová, K. (2006). Toxicity and DNA damage in tobacco and potato plants growing on soil polluted with heavy metals. Ecotoxicol. Environ. Saf. 65, 420-426. doi: 10.1016/j.ecoenv.2005.08.006

Giller, K. E., Witter, E., and Mcgrath, S. P. (1998). Toxicity of heavy metals to microorganisms and microbial processes in agricultural soils: a review. Soil Biol. Biochem. 30, 1389-1414. doi: 10.1016/S0038-0717(97)00270-8

Gimeno-García, E., Andreu, V., and Boluda, R. (1996). Heavy metals incidence in the application of inorganic fertilizers and pesticides to rice farming soils. Environ. Pollut. 92, 19-25. doi: 10.1016/0269-7491(95)00090-9

Glick, B. R. (2014). Bacteria with ACC deaminase can promote plant growth and help to feed the world. Microbiol. Res. 169, 30-39. doi: 10.1016/j.micres.2013.09.009

Gonçalves, M. M. M., Da Costa, A. C. A., Leite, S. G. F., and Sant'Anna, G. L. (2007). Heavy metal removal from synthetic wastewaters in an anaerobic bioreactor using stillage from ethanol distilleries as a carbon source. Chemosphere 69, 1815-1820. doi: 10.1016/j.chemosphere.2007.05.074 
Gope, M., Masto, R. E., George, J., Hoque, R. R., and Balachandran, S. (2017). Bioavailability and health risk of some potentially toxic elements $(\mathrm{Cd}, \mathrm{Cu}, \mathrm{Pb}$ and $\mathrm{Zn}$ ) in street dust of Asansol, India. Ecotoxicol. Environ. Saf. 138, 231-241. doi: 10.1016/j.ecoenv.2017.01.008

Gratão, P. L., Polle, A., Lea, P. J., and Azevedo, R. A. (2005). Making the life of heavy metal-stressed plants a little easier. Funct. Plant Biol. 32, 481-494. doi: 10.1071/FP05016

Gray, C. W., McLaren, R. G., and Roberts, A. H. (2003). Atmospheric accessions of heavy metals to some New Zealand pastoral soils. Sci. Tot. Environ. 305, 105-115. doi: 10.1016/S0048-9697(02)00404-7

Greszta, J., Braniewski, S., Marezynska-Galkowska, K., and Nosek, A. (1979). Ekologia. Polska 27:397.

Grotz, N., and Guerinot, M. L. (2006). Molecular aspects of Cu, Fe and $\mathrm{Zn}$ homeostasis in plants. Biochim. Biophys. Acta 1763, 595-608. doi: 10.1016/j.bbamcr.2006.05.014

Gupta, A. K., Singh, R. P., Singh, A., and Ibrahim, M. H. (2010). "Effects of heavy metal and metalloid contamination on the soil microbial response: an overview," in Microbial Ecology of Tropical Soils, eds A. S. F. de Araújo and M. D. V. B. Figueiredo (Hauppauge, NY: Nova Science Publisher), 1-16.

Hall, J. L. (2002). Cellular mechanisms for heavy metal detoxification and tolerance. J. Exp. Bot. 53, 1-11. doi: 10.1093/jexbot/53.366.1

Hall, J. L., and Williams, L. E. (2003). Transition metal transporters in plants. J. Exp. Bot. 54, 2601-2613. doi: 10.1093/jxb/erg303

Hamsa, N., Yogesh, G. S., Koushik, U., and Patil, L. (2017). Nitrogen transformation in soil: effect of heavy metals. Int. J. Curr. Microbiol. Appl. Sci. 6, 816-832. doi: 10.20546/ijcmas.2017.605.092

Hanikenne, M., Krämer, U., Demoulin, V., and Baurain, D. (2005). A comparative inventory of metal transporters in the green alga Chlamydomonas reinhardtii and the red alga Cyanidioschizon merolae. Plant Physiol. 137, 428-446. doi: $10.1104 /$ pp. 104.054189

Harris, G. K., and Shi, X. (2003). Signaling by carcinogenic metals and metal-induced reactive oxygen species. Mutat. Res. 533, 183-200. doi: 10.1016/j.mrfmmm.2003.08.025

Harris, J. (2009). Soil microbial communities and restoration ecology: facilitators or followers? Science 325, 573-574. doi: 10.1126/science.1172975

Hassan, Z., and Aarts, M. G. (2011). Opportunities and feasibilities for biotechnological improvement of $\mathrm{Zn}$, Cd or Ni tolerance and accumulation in plants. Environ. Exp. Bot. 72, 53-63. doi: 10.1016/j.envexpbot.2010.04.003

Hattab, S., Hattab, S., Flores-Casseres, M. L., Bousseta, H., Doumas, P., Hernandez, L. E., et al. (2016). Characterization of lead-induced stress molecular biomarkers in Medicago sativa plants. Environ. Exp. Bot. 123, 1-12. doi: 10.1016/j.envexpbot.2015.10.005

Hattori, H. (1991). Influence of cadmium on decomposition of glucose and cellulose in soil. Soil Sci. Plant Nutr. 37, 39-45. doi: 10.1080/00380768.1991.10415008

Hattori, H. (1992). Influence of heavy metals on soil microbial activities. Soil Sci. Plant Nutr. 38, 93-100. doi: 10.1080/00380768.1992.10416956

He, J., Qin, J., Long, L., Ma, Y., Li, H., Li, K., et al. (2011). Net cadmium flux and accumulation reveal tissue-specific oxidative stress and detoxification in Populus $\times$ canescens. Physiol. Plant. 143, 50-63. doi: 10.1111/j.1399-3054.2011.01487.x

Hirata, A., Corcoran, G. B., and Hirata, F. (2011). Carcinogenic heavy metals, $\mathrm{As}^{3+}$ and $\mathrm{Cr}^{6+}$, increase affinity of nuclear mono-ubiquitinated annexin A1 for DNA containing 8-oxo-guanosine, and promote translesion DNA synthesis. Toxicol. Appl. Pharmacol. 252, 159-164. doi: 10.1016/j.taap.2011.01.022

Hogsden, K. L., and Harding, J. S. (2012). Consequences of acid mine drainage for the structure and function of benthic stream communities: a review. Freshw. Sci. 31, 108-120. doi: 10.1899/11-091.1

Holmström, K. M., and Finkel, T. (2014). Cellular mechanisms and physiological consequences of redox-dependent signalling. Nat. Rev. Mol. Cell Biol. 15, 411-421. doi: 10.1038/nrm3801

Hu, B., Liang, D., Liu, J., and Xie, J. (2013). Ecotoxicological effects of copper and selenium combined pollution on soil enzyme activities in planted and unplanted soils. Environ. Toxicol. Chem. 32, 1109-1116. doi: 10.1002/etc.2152

Hu, X. F., Jiang, Y., Shu, Y., Hu, X., Liu, L., and Luo, F. (2014). Effects of mining wastewater discharges on heavy metal pollution and soil enzyme activity of the paddy fields. J. Geochem. Explor. 147, 139-150. doi: 10.1016/j.gexplo.2014.08.001
Huang, S. S., Liao, Q. L., Hua, M., Wu, X. M., Bi, K. S., Yan, C. Y., et al. (2007). Survey of heavy metal pollution and assessment of agricultural soil in Yangzhong district, Jiangsu Province, China. Chemosphere 67, 2148-2155. doi: 10.1016/j.chemosphere.2006.12.043

Illmer, P., and Schinner, F. (1991). Effects of lime and nutrient salts on the microbiological activities of forest soils. Biol. Fertil. Soils 11, 261-266. doi: 10.1007/BF00335845

Inouhe, M., Sakuma, Y., Chatterjee, S., Datta, S., Jagetiya, B. L., Voronina, A. V., et al. (2015). "General roles of phytochelatins and other peptides in plant defense mechanisms against oxidative stress/primary and secondary damages induced by heavy metal," in Reactive Oxygen Species and Oxidative Damage in Plants Under Stress, eds D. Gupta, J. M. Palma, and F. J. Corpas (Cham: Springer International Publishing), 219-245.

Islam, E., Khan, M. T., and Irem, S. (2015). Biochemical mechanisms of signaling: perspectives in plants under arsenic stress. Ecotoxicol. Environ. Saf. 114, 126-133. doi: 10.1016/j.ecoenv.2015.01.017

Islam, M. A., Romić, D., Akber, M. A., and Romić, M. (2017). Trace metals accumulation in soil irrigated with polluted water and assessment of human health risk from vegetable consumption in Bangladesh. Environ. Geochem. Health. doi: 10.1007/s10653-017-9907-8. [Epub ahead of print].

Israr, M., Jewell, A., Kumar, D., and Sahi, S. V. (2011). Interactive effects of lead, copper, nickel and zinc on growth, metal uptake and antioxidative metabolism of Sesbania drummondii. J. Haz. Mater. 186, 1520-1526. doi: 10.1016/j.jhazmat.2010.12.021

Järup, L. (2003). Hazards of heavy metal contamination. Br. Med. Bull. 68, 167-182. doi: 10.1093/bmb/ldg032

Jiang, W., and Liu, D. (2010). Pb-induced cellular defense system in the root meristematic cells of Allium sativum L. BMC Plant. Biol. 10:40. doi: 10.1186/1471-2229-10-40

Jonak, C., Nakagami, H., and Hirt, H. (2004). Heavy metal stress. Activation of distinct mitogen-activated protein kinase pathways by copper and cadmium. Plant Physiol. 136, 3276-3283. doi: 10.1104/pp.104.045724

Jones, G. C., Corin, K. C., van Hille, R. P., and Harrison, S. T. (2011). The generation of toxic reactive oxygen species (ROS) from mechanically activated sulphide concentrates and its effect on thermophilic bioleaching. Miner. Eng. 241, 198-1208. doi: 10.1016/j.mineng.2011.05.016

Kao, P. H., Huang, C. C., and Hseu, Z. Y. (2006). Response of microbial activities to heavy metals in a neutral loamy soil treated with biosolid. Chemosphere 64, 63-70. doi: 10.1016/j.chemosphere.2005.11.039

Kasprzak, K. S. (1995). Possible role of oxidative damage in metalinduced carcinogenesis. Cancer Invest. 13, 411-430. doi: 10.3109/07357909509031921

Kelepertzis, E. (2014). Accumulation of heavy metals in agricultural soils of Mediterranean: insights from Argolida basin, Peloponnese, Greece. Geoderma 221, 82-90. doi: 10.1016/j.geoderma.2014.01.007

Khan, M. U., Malik, R. N., and Muhammad, S. (2013). Human health risk from Heavy metal via food crops consumption with wastewater irrigation practices in Pakistan. Chemosphere 93, 2230-2238. doi: 10.1016/j.chemosphere.2013. 07.067

Khan, S., Cao, Q., Zheng, Y. M., Huang, Y. Z., and Zhu, Y. G. (2008). Health risks of heavy metals in contaminated soils and food crops irrigated with wastewater in Beijing, China. Environ. Pollut. 152, 686-692. doi: 10.1016/j.envpol.2007.06.056

Khan, S., Hesham, A. E. L., Qiao, M., Rehman, S., and He, J. Z. (2010). Effects of $\mathrm{Cd}$ and $\mathrm{Pb}$ on soil microbial community structure and activities. Environ. Sci. Pollut. Res. 17, 288-296. doi: 10.1007/s11356-009-0134-4

Klatte, M., Schuler, M., Wirtz, M., Fink-Straube, C., Hell, R., and Bauer, P. (2009). The analysis of Arabidopsis nicotianamine synthase mutants reveals functions for nicotianamine in seed iron loading and iron deficiency responses. Plant Physiol. 150, 257-271. doi: 10.1104/pp.109.136374

Kovácik, J., Klejdus, B., Hedbavny, J., and Backor, M. (2010). Effect of copper and salicylic acid on phenolic metabolites and free amino acids in Scenedesmusquadricauda (Chlorophyceae). Plant Sci. 178, 307-311. doi: 10.1016/j.plantsci.2010.01.009

Kozlov, M. V., and Zvereva, E. L. (2015). Decomposition of birch leaves in heavily polluted industrial barrens: relative importance of leaf quality and site of exposure. Environ. Sci. Pollut. Res. 22, 9943-9950. doi: 10.1007/s11356-015-4165-8

Kumar, D., Singh, D. P., Barman, S. C., and Kumar, N. (2016). "Heavy metal and their regulation in plant system: an overview," in Plant Responses to Xenobiotics, 
eds A. Singh, S. Prasad, and R. Singh (Singapore: Springer Nature Singapore Pte. Ltd.), 19-38.

Küpper, H., Lombi, E., Zhao, F. J., and McGrath, S. P. (2000). Cellular compartmentation of cadmium and zinc in relation to other elements in the hyperaccumulator Arabidopsis halleri. Planta 212, 75-84. doi: $10.1007 / \mathrm{s} 004250000366$

Lee, C. S., Li, X. D., Zhang, G., Li, J., Ding, A. J., and Wang, T. (2007). Heavy metals and $\mathrm{Pb}$ isotopic composition of aerosols in urban and suburban areas of Hong Kong and Guangzhou, South China-evidence of the long-range transport of air contaminants. Atmos. Environ. 41, 432-447. doi: 10.1016/j.atmosenv.2006.07.035

Lenntech Water Treatment and Air Purification (2004). Water Treatment. Published by Lenntech, Rotterdamseweg. Available online at: www.excelwater. com/thp/filters/Water-Purification.htm

Li, L., Wang, Y., and Shen, W. (2012). Roles of hydrogen sulfide and nitric oxide in the alleviation of cadmium-induced oxidative damage in alfalfa seedling roots. Biometals 25, 617-631. doi: 10.1007/s10534-012-9551-9

Li, X., Yang, Y., Jia, L., Chen, H., and Wei, X. (2013). Zinc-induced oxidative damage, antioxidant enzyme response and proline metabolism in roots and leaves of wheat plants. Ecotoxicol. Environ. Saf. 89, 150-157. doi: 10.1016/j.ecoenv.2012.11.025

Liu, G., Yu, Y., Hou, J., Xue, W., Liu, X., Liu, Y., et al. (2014). An ecological risk assessment of heavy metal pollution of the agricultural ecosystem near a leadacid battery factory. Ecol. Indic. 47, 210-218. doi: 10.1016/j.ecolind.2014.04.040

Liu, T., Liu, S., Guan, H., Ma, L., Chen, Z., Gu, H., et al. (2009). Transcriptional profiling of Arabidopsis seedlings in response to heavy metal lead ( $\mathrm{Pb})$. Environ. Exp. Bot. 67, 377-386. doi: 10.1016/j.envexpbot.2009.03.016

Lombi, E., Tearall, K. L., Howarth, J. R., Zhao, F. J., Hawkesford, M. J., and McGrath, S. P. (2002). Influence of iron status on cadmium and zinc uptake by different ecotypes of the hyperaccumulator Thlaspi caerulescens. Plant Physiol. 128, 1359-1367. doi: 10.1104/pp.010731

Ma, J. F., Hiradate, S., and Matsumoto, H. (1998). High aluminum resistance in buckwheat II. Oxalic acid detoxifies aluminum internally. Plant Physiol. 117, 753-759. doi: 10.1104/pp.117.3.753

Ma, L. Q., Komar, K. M., Tu, C., Zhang, W., Cai, Y., and Kennelley, E. D. (2001). A fern that hyperaccumulates arsenic. Nature 409, 579-579. doi: $10.1038 / 35054664$

Ma, T. H., Xu, Z., Xu, C., McConnell, H., Rabago, E. V., Arreola, G. A., et al. (1995). The improved Allium/Vicia root tip micronucleus assay for clastogenicity of environmental pollutants. Mutat. Res. 334, 185-195. doi: 10.1016/0165-1161(95)90010-1

Mahmood, S., Ishtiaq, S., Yasin, G., and Irshad, A. (2016). Dose dependent rhizospheric $\mathrm{Ni}$ toxicity evaluation: membrane stability and antioxidant potential of Vigna species. Chil. J. Agric. Res. 76, 378-384. doi: $10.4067 /$ S0718-58392016000300017

Maksymiec, W. (2007). Signalling responses in plants to heavy metal stress. Acta Physiol. Plant. 29, 177-187. doi: 10.1007/s11738-007-0036-3

Malar, S., Favas, P. J. C., Sahi, S. V., and Venkatachalam, P. (2014). Effect of lead on phytotoxicity, growth, biochemical alterations and its role on genomic template stability in Sesbania grandiflora: a potential plant for phytoremediation. Ecotoxicol. Environ. Saf. 108, 249-257. doi: 10.1016/j.ecoenv.2014.05.018

Malar, S., Sahi, S. V., Favas, P. J., and Venkatachalam, P. (2015). Mercury heavy-metal-induced physiochemical changes and genotoxic alterations in water hyacinths [Eichhornia crassipes (Mart.)]. Environ. Sci. Pollut. Res. 22, 4597-4608. doi: 10.1007/s11356-014-3576-2

Malik, Z., Ahmad, M., Abassi, G. H., Dawood, M., Hussain, A., and Jamil, M. (2017). "Agrochemicals and soil microbes: interaction for soil health," in Xenobiotics in the Soil Environment:Monitoring, Toxicity and Management, ed M. Z. Hashmi (Cham: Springer International Publishing), 139-152.

Manikandan, R., Ezhili, N., and Venkatachalam, P. (2016). Phosphorus supplementation alleviation of the cadmium-induced toxicity by modulating oxidative stress mechanisms in vetiver grass [Chrysopogon zizanioides (L.) Roberty]. J. Environ. Eng. 142:C4016003. doi: 10.1061/(ASCE)EE.1943-7870.0001112

Manikandan, R., Sahi, S. V., and Venkatachalam, P. (2015). Impact assessment of mercury accumulation and biochemical and molecular response of Mentha arvensis: a potential hyperaccumulator plant. Sci. World J. 2015:715217. doi: $10.1155 / 2015 / 715217$
Marcato-Romain, C. E., Guiresse, M., Cecchi, M., Cotelle, S., and Pinelli, E. (2009). New direct contact approach to evaluate soil genotoxicity using the Vicia faba micronucleus test. Chemosphere 77, 345-350. doi: 10.1016/j.chemosphere.2009.07.016

Marrugo-Negrete, J., Pinedo-Hernández, J., and Díez, S. (2017). Assessment of heavy metal pollution, spatial distribution and origin in agricultural soils along the Sinú River Basin, Colombia. Environ. Res. 154, 380-388. doi: 10.1016/j.envres.2017.01.021

Marschner, B., and Kalbitz, K. (2003). Controls of bioavailability and biodegradability of dissolved organic matter in soils. Geoderma 113, 211-235. doi: 10.1016/S0016-7061(02)00362-2

Marshall, F. M., Holden, J., Ghose, C., Chisala, B., Kapungwe, E., Volk, J., et al. (2007). Contaminated Irrigation Water and Food Safety for the Urban and Peri-Urban Poor: Appropriate Measures for Monitoring and Control from Field Research in India and Zambia. Incpetion Report DFID Enkar, 8160.

Mates, J. M. (2000). Effects of antioxidant enzymes in the molecular control of reactive oxygen species toxicology. Toxicology 153, 83-104. doi: 10.1016/S0300-483X(00)00306-1

McEnroe, N. A., and Helmisaari, H. S. (2001). Decomposition of coniferous forest litter along a heavy metal pollution gradient, south-west Finland. Environ. Pollut. 113, 11-18. doi: 10.1016/S0269-7491(00)00163-9

McLaughlin, M. J., Parker, D. R., and Clarke, J. M. (1999). Metals and micronutrients-food safety issues. Field Crops Res. 60, 143-163. doi: 10.1016/S0378-4290(98)00137-3

Mesquita, V. A., Silva, C. F., and Soares, E. V. (2016). Toxicity induced by a metal mixture $(\mathrm{Cd}, \mathrm{Pb}$ and $\mathrm{Zn})$ in the yeast Pichia kudriavzevii: the role of oxidative stress. Curr. Microbiol. 72, 545-550. doi: 10.1007/s00284-016-0987-y

Michelet, L., Zaffagnini, M., Massot, V., Keryer, E., Vanacker, H., Miginiac-Maslow, M., et al. (2006). Thioredoxins, glutaredoxins, and glutathionylation: new crosstalks to explore. Photosynth. Res. 89, 225-245. doi: 10.1007/s11120-006-9096-2

Mikkelsen, J. P. (1974). Indvirkning af bly pa jordbundens mikrobiologiske aktivitet. Tidsskrift Planteavl 78, 509-516.

Mittler, R. (2017). ROS are good. Trends Plant Sci. 22, 11-19. doi: 10.1016/j.tplants.2016.08.002

Mittler, R., Vanderauwera, S., Suzuki, N., Miller, G., Tognetti, V. B., Vandepoele, K., et al. (2011). ROS signalling: the new wave? Trends Plant Sci. 16, 300-309. doi: 10.1016/j.tplants.2011.03.007

Monge, G., Jimenez-Espejo, F. J., García-Alix, A., Martínez-Ruiz, F., Mattielli, N., Finlayson, C., et al. (2015). Earliest evidence of pollution by heavy metals in archaeological sites. Sci. Rep. 5:14252. doi: 10.1038/srep14252

Morina, F., Jovanovic, L., Mojovic, M., Vidovic, M., Pankovic, D., and VeljovicJovanovic, S. (2010). Zinc-induced oxidative stress in Verbascumthapsus is caused by an accumulation of reactive oxygen species and quinhydrone in the cell wall. Physiol. Plant. 140, 209-224. doi: 10.1111/j.1399-3054.2010.01399.x

Muhlbachova, G., Sagova-Mareckova, M., Omelka, M., Szakova, J., and Tlustos, P. (2015). The influence of soil organic carbon on interactions between microbial parameters and metal concentrations at a long-term contaminated site. Sci. Tot. Environ. 502, 218-223. doi: 10.1016/j.scitotenv.2014.08.079

Nagajyoti, P. C., Lee, K. D., and Sreekanth, T. V. M. (2010). Heavy metals, occurrence and toxicity for plants: a review. Environ. Chem. Lett. 8, 199-216. doi: $10.1007 / \mathrm{s} 10311-010-0297-8$

Nahar, K., Hasanuzzaman, M., Alam, M. M., Rahman, A., Suzuki, T., and Fujita, M. (2016). Polyamine and nitric oxide crosstalk: antagonistic effects on cadmium toxicity in mung bean plants through upregulating the metal detoxification, antioxidant defense and methylglyoxal detoxification systems. Ecotoxicol. Environ. Saf. 126, 245-255. doi: 10.1016/j.ecoenv.2015.12.026

Naidu, R., Kookana, R. S., Sumner, M. E., Harter, R. D., and Tiller, K. G. (1997). Cadmium sorption and transport in variable charged soils: a review. J. Environ. Qual. 26, 602-617. doi: 10.2134/jeq1997.00472425002600030004x

Nair, A., Juwarkar, A. A., and Singh, S. K. (2007). Production and characterization of siderophores and its application in arsenic removal from contaminated soil. Water Air Soil Pollut. 180, 199-212. doi: 10.1007/s11270-0069263-2

Nakagami, H., Pitzschke, A., and Hirt, H. (2005). Emerging MAP kinase pathways in plant stress signalling. Trends Plant Sci. 10, 339-346. doi: 10.1016/j.tplants.2005.05.009 
Nayak, A. K., Raja, R., Rao, K. S., Sukla, A. K., Mohanty, S., Sahid, M., et al. (2015). Effect of fly ash application on soil microbial response and heavy metal accumulation in soil and rice plan. Ecotoxicol. Environ. Saf. 114, 257-262. doi: 10.1016/j.ecoenv.2014.03.033

Niassy, S., and Diarra, K. (2012). "Effect of organic inputs in urban agriculture and their optimization for poverty alleviation in Senegal, West Africa," in Organic Fertilizers: Types, Production and Environmental Impact, ed R. P. Singh (Hauppauge, NY: Nova Science Publisher), 1-22.

Nicholson, F. A., Smith, S. R., Alloway, B. J., Carlton-Smith, C., and Chambers, B. J. (2003). An inventory of heavy metals inputs to agricultural soils in England and Wales. Sci. Tot. Environ. 311, 205-219. doi: 10.1016/S0048-9697(03)00139-6

Noctor, G., Mhamdi, A., Chaouch, S., Han, Y. I., Neukermans, J., Marquez-Garcia, B. E. L. E. N., et al. (2012). Glutathione in plants: an integrated overview. Plant Cell Environ. 35, 454-484. doi: 10.1111/j.1365-3040.2011.02400.x

Noinaj, N., Guillier, M., Barnard, T. J., and Buchanan, S. K. (2010). TonBdependent transporters: regulation, structure, and function. Annu. Rev. Microbiol. 64, 43-60. doi: 10.1146/annurev.micro.112408.134247

Nwuche, C. O., and Ugoji, E. O. (2008). Effects of heavy metal pollution on the soil microbial activity. Int. J. Environ. Sci. Technol. 5, 409-414. doi: $10.1007 / \mathrm{BF} 03326036$

O'Brien, S., Hodgson, D. J., and Buckling, A. (2014). Social evolution of toxic metal bioremediation in Pseudomonas aeruginosa. Proc. R. Soc. B 281:20140858. doi: 10.1098/rspb.2014.0858

Ogawa, S., Yoshidomi, T., and Yoshimura, E. (2011). Cadmium (II)-stimulated enzyme activation of Arabidopsis thaliana phytochelatin synthase. J. Inorg. Biochem. 105, 111-117. doi: 10.1016/j.jinorgbio.2010.09.011

Olaniran, A. O., Balgobind, A., and Pillay, B. (2013). Bioavailability of heavy metals in soil: impact on microbial biodegradation of organic compounds and possible improvement strategies. Int. J. Mol. Sci. 14, 10197-10228. doi: 10.3390/ijms140510197

Oliveira, A., and Pampulha, M. E. (2006). Effects of long-term heavy metal contamination on soil microbial characteristics. J. Biosci. Bioenegry 102, 157-161. doi: 10.1263/jbb.102.157

Oliveira, S. C. B., Corduneanu, O., and Oliveira-Brett, A. M. (2008). In situ evaluation of heavy metal-DNA interactions using an electrochemical DNA biosensor. Bioelectrochemistry 72, 53-58. doi: 10.1016/j.bioelechem.2007.11.004

Ovečka, M., and Takác, T. (2014). Managing heavy metal toxicity stress in plants: biological and biotechnological tools. Biotechnol. Adv. 32, 73-86. doi: 10.1016/j.biotechadv.2013.11.011

Pan, J., and Yu, L. (2011). Effects of $\mathrm{Cd}$ or/and $\mathrm{Pb}$ on soil enzyme activities and microbial community structure. Ecol. Eng. 37, 1889-1894. doi: 10.1016/j.ecoleng.2011.07.002

Patra, M., Bhowmik, N., Bandopadhyay, B., and Sharma, A. (2004). Comparison of mercury, lead and arsenic with respect to genotoxic effects on plant systems and the development of genetic tolerance. Environ. Exp. Bot. 52, 199-223. doi: 10.1016/j.envexpbot.2004.02.009

Pavilonis, B., Grassman, J., Johnson, G., Diaz, Y., and Caravanos, J. (2017). Characterization and risk of exposure to elements from artisanal gold mining operations in the Bolivian Andes. Environ. Res. 154, 1-9. doi: 10.1016/j.envres.2016.12.010

Paz-Ferreiro, J., and Fu, S. (2016). Biological indices for soil quality evaluation: perspectives and limitations. Land Degrad. Dev. 27, 14-25. doi: 10.1002/ldr.2262

Pinto, E., Sigaud-kutner, T., Leitao, M. A., Okamoto, O. K., Morse, D., and Colepicolo, P. (2003). Heavy metal-induced oxidative stress in algae. J. Phycol. 39, 1008-1018. doi: 10.1111/j.0022-3646.2003.02-193.x

Porta, H., and Rocha-Sosa, M. (2002). Plant lipoxygenases. Physiological and molecular features. Plant Physiol. 130, 15-21. doi: 10.1104/pp.010787

Pourrut, B., Jean, S., Silvestre, J., and Pinelli, E. (2011). Lead-induced DNA damage in Viciafaba root cells: potential involvement of oxidative stress. Mutat. Res. 726, 123-128. doi: 10.1016/j.mrgentox.2011.09.001

Prévéral, S., Gayet, L., Moldes, C., Hoffmann, J., Mounicou, S., Gruet, A., et al. (2009). A common highly conserved cadmium detoxification mechanism from bacteria to humans heavy metal tolerance conferred by the ATPbinding cassette $(\mathrm{ABC})$ transporter SpHMT1 requires glutathione but not metal-chelating phytochelatin peptides. J. Biol. Chem. 284, 4936-4943. doi: $10.1074 /$ jbc.M808130200
Pucciariello, C., Banti, V., and Perata, P. (2012). ROS signaling as common element in low oxygen and heat stresses. Plant Physiol. Biochem. 59, 3-10. doi: 10.1016/j.plaphy.2012.02.016

Qin, R., Wang, C., Chen, D., Björn, L. O., and Li, S. (2015). Copper-induced root growth inhibition of Allium cepa var. agrogarum L. involves disturbances in cell division and DNA damage. Environ. Toxicol. Chem. 34, 1045-1055. doi: $10.1002 /$ etc. 2884

Qun, D. C., and Xiao, W. H. (1995). Cytogenetic toxic effects of heavy metals on Viciafaba and studies into the Vicia micronucleus. Acta Bot. Sin. 37, 14-24.

Qureshi, A. S., Hussain, M. I., Ismail, S., and Khan, Q. M. (2016). Evaluating heavy metal accumulation and potential health risks in vegetables irrigated with treated wastewater. Chemosphere 163, 54-61. doi: 10.1016/j.chemosphere.2016.07.073

Rajewska, I., Talarek, M., and Bajguz, A. (2016). Brassinosteroids and response of plants to heavy metals action. Front. Plant Sci. 7:629. doi: $10.3389 /$ fpls.2016.00629

Rajkumar, M., Ae, N., Prasad, M. N. V., and Freitas, H. (2010). Potential of siderophore-producing bacteria for improving heavy metal phytoextraction. Trends Biotechnol. 28, 142-149. doi: 10.1016/j.tibtech.2009.12.002

Rascio, N., and Navari-Izzo, F. (2011). Heavy metal hyperaccumulating plants: how and why do they do it? And what makes them so interesting? Plant Sci. 180, 169-181 doi: 10.1016/j.plantsci.2010.08.016

Raskin, I., Kumar, P. N., Dushenkov, S., and Salt, D. E. (1994). Bioconcentration of heavy metals by plants. Curr. Opin. Biotechnol. 5, 285-290. doi: 10.1016/0958-1669(94)90030-2

Raskin, I., Smith, R. D., and Salt, D. E. (1997). Phytoremediation of metals: using plants to remove pollutants from the environment. Curr. Opin. Biotechnol. 8, 221-226. doi: 10.1016/S0958-1669(97)80106-1

Rea, P. A. (2012). Phytochelatin synthase: of a protease a peptide polymerase made. Physiol. Plant. 145, 154-164. doi: 10.1111/j.1399-3054.2012.01571.x

Reczek, C. R., and Chandel, N. S. (2015). ROS-dependent signal transduction. Curr. Opin. Cell Biol. 33, 8-13. doi: 10.1016/j.ceb.2014.09.010

Rhee, J. S., Yu, I. T., Kim, B. M., Jeong, C. B., Lee, K. W., Kim, M. J., et al. (2013). Copper induces apoptotic cell death through reactive oxygen species-triggered oxidative stress in the intertidal copepod Tigriopus japonicus. Aquat. Toxicol. 132, 182-189. doi: 10.1016/j.aquatox.2013.02.013

Robinson, B. H., Lombi, E., Zhao, F. J., and McGrath, S. P. (2003). Uptake and distribution of nickel and other metals in the hyperaccumulator Berkheya coddii. New Phytol. 158, 279-285. doi: 10.1046/j.1469-8137.2003.00743.x

Rodriguez, M. C., Petersen, M., and Mundy, J. (2010). Mitogen-activated protein kinase signalling in plants. Annu. Rev. Plant Biol. 61, 621-649. doi: 10.1146/annurev-arplant-042809-112252

Ross, S. M. (1994). Toxic Metals in Soil-Plant Systems. Chichester: Wiley, 4.

Rother, J. A., Millbank, J. W., and Thornton, I. (1982). Seasonal fluctuations in nitrogen fixation (acetylene reduction) by free-living bacteria in soils contaminated with cadmium, lead and zinc. J. Soil Sci. 33, 101-113. doi: 10.1111/j.1365-2389.1982.tb01751.x

Rout, T. K., Masto, R. E., Ram, L. C., George, J., and Padhy, P. K. (2013). Assessment of human health risks from heavy metals in outdoor dust samples in a coal mining area. Environ. Geochem. Health 35, 347-356. doi: 10.1007/s10653-012-9499-2

Ruan, X. M., Luo, F., Li, D. D., Zhang, J., Liu, Z. H., Xu, W. L., et al. (2011). Cotton BCP genes encoding putative blue copper-binding proteins are functionally expressed in fiber development and involved in response to high-salinity and heavy metal stresses. Physiol. Plant. 141, 71-83. doi: 10.1111/j.1399-3054.2010.01420.x

Rühling, Å., Bååth, E., Nordgren, A., and Söderström, B. (1984). Fungi in metalcontaminated soil near the Gusum brass mill, Sweden. Ambio 13, 34-36.

Saha, M., Sarkar, S., Sarkar, B., Sharma, B. K., Bhattacharjee, S., and Tribedi, P. (2016). Microbial siderophores and their potential applications: a review. Environ. Sci. Pollut Res. 23, 3984-3999. doi: 10.1007/s11356-015-4294-0

Saravanan, V. S., Madhaiyan, M., and Thangaraju, M. (2007). Solubilization of zinc compounds by the diazotrophic, plant growth promoting bacterium Gluconacetobacter diazotrophicus. Chemosphere 66, 1794-1798. doi: 10.1016/j.chemosphere.2006.07.067

Saxena, P., and Misra, N. (2010). "Remediation of heavy metal contaminated tropical land," in Soil Heavy Metals Soil Biology, eds I. Sherameti and A. Varma (Berlin; Heidelberg: Springer) 431-477. 
Schellingen, K., Van Der Straeten, D., Vandenbussche, F., Prinsen, E., Remans, T., Vangronsveld, J., et al. (2014). Cadmium-induced ethylene production and responses in Arabidopsis thaliana rely on ACS2 and ACS6 gene expression. BMC Plant Biol. 14:214. doi: 10.1186/s12870-014-0214-6

Schickler, H., and Caspi, H. (1999). Response of antioxidant enzymes to nickel and cadmium stress in hyperaccumulator plants of the genus Alyssum. Physiol. Plant. 105, 39-44. doi: 10.1034/j.1399-3054.1999.105107.x

Schimel, J., Balser, T. C., and Wallenstein, M. (2007). Microbial stress-response physiology and its implications for ecosystem function. Ecology 88, 1386-1394. doi: 10.1890/06-0219

Seaward, M. R. D., and Richardson, D. H. S. (1989). "Atmospheric sources of metal pollution and effects on vegetation," in Heavy Metal Tolerance in Plants Evolutionary Aspects, ed A. J. Shaw (Boca Raton, FL: CRC Press), 75-94.

Shahid, M., Pourrut, B., Dumat, C., Nadeem, M., Aslam, M., and Pinelli, E. (2014). Heavy-metal-induced reactive oxygen species: phytotoxicity and physicochemical changes in plants. Rev. Environ. Contam. Toxicol. 232, 1-44. doi: 10.1007/978-3-319-06746-9_1

Sharma, B., Sarkar, A., Singh, P., and Singh, R. P. (2017). Agricultural utilization of biosolids: a review on potential effects on soil and plant grown. Waste Manage. 64, 117-132. doi: 10.1016/j.wasman.2017.03.002

Sharma, R. K., Agrawal, M., and Marshall, F. (2007). Heavy metal contamination of soil and vegetables in suburban areas of Varanasi, India. Ecotoxicol. Environ. Saf. 66, 258-266. doi: 10.1016/j.ecoenv.2005.11.007

Sharma, S. S., Dietz, K. J., and Mimura, T. (2016). Vacuolar compartmentalization as indispensable component of heavy metal detoxification in plants. Plant Cell Environ. 39, 1112-1126. doi: 10.1111/pce.12706

Sharma, S. S., Kaul, S., Metwally, A., Goyal, K. C., Finkemeier, I., and Dietz, K. J. (2004). Cadmium toxicity to barley (Hordeum vulgare) as affected by varying $\mathrm{Fe}$ nutritional status. Plant Sci. 166, 1287-1295. doi: 10.1016/j.plantsci.2004.01.006

Shen, Y., Zhang, Y., Chen, J., Lin, H., Zhao, M., Peng, H., et al. (2013). Genome expression profile analysis reveals important transcripts in maize roots responding to the stress of heavy metal Pb. Physiol. Plant. 147, 270-282. doi: 10.1111/j.1399-3054.2012.01670.x

Sheng, X. F., Xia, J. J., Jiang, C. Y., He, L. Y., and Qian, M. (2008). Characterization of heavy metal-resistant endophytic bacteria from rape (Brassica napus) roots and their potential in promoting the growth and lead accumulation of rape. Environ. Pollut. 156, 1164-1170. doi: 10.1016/j.envpol.2008.04.007

Sidhu, G. P. S., Singh, H. P., Batish, D. R., and Kohli, R. K. (2016). Effect of lead on oxidative status, antioxidative response and metal accumulation in Coronopus didymus. Plant Physiol. Biochem. 105, 290-296. doi: 10.1016/j.plaphy.2016.05.019

Silva, S., Silva, P., Oliveira, H., Gaivão, I., Matos, M., Pinto-Carnide, O., et al. (2017). $\mathrm{Pb}$ low doses induced genotoxicity in Lactuca sativa plants. Plant Physiol. Biochem. 112, 109-116. doi: 10.1016/j.plaphy.2016.12.026

Singh, N., and Ma, L. Q. (2006). Arsenic speciation, and arsenic and phosphate distribution in arsenic hyperaccumulator Pteris vittata L. and non-hyperaccumulator Pteris ensiformis L. Environ. Pollut. 141, 238-246. doi: 10.1016/j.envpol.2005.08.050

Singh, R. P., and Agrawal, M. (2007). Effects of sewage sludge amendment on heavy metal accumulation and consequent responses of Beta vulgaris plants. Chemosphere 67, 2229-2240. doi: 10.1016/j.chemosphere.2006.12.019

Singh, R. P., and Agrawal, M. (2008). Potential benefits and risks of land application of sewage sludge. Waste Manage. 28, 347-358. doi: 10.1016/j.wasman.2006.12.010

Singh, R. P., and Agrawal, M. (2009). Use of sewage sludge as fertiliser supplement for Abelmoschus esculentus plants: physiological, biochemical and growth responses. Int. J. Environ. Waste Manage. 3, 91-106. doi: 10.1504/IJEWM.2009.024702

Singh, R. P., and Agrawal, M. (2010a). Effect of different sewage sludge applications on growth and yield of Vigna radiata L. field crop: Metal uptake by plant. Ecol. Eng. 36, 969-972. doi: 10.1016/j.ecoleng.2010.03.008

Singh, R. P., and Agrawal, M. (2010b). Variations in heavy metal accumulation, growth and yield of rice plants grown at different sewage sludge amendment rates. Ecotoxicol. Environ. Saf. 73, 632-641. doi: 10.1016/j.ecoenv.2010. 01.020

Singh, R. P., and Agrawal, M. (2010c). Biochemical and physiological responses of rice (Oryza sativa L.) grown on different sewage sludge amendments rates. Bull. Environ. Contam. Toxicol. 84, 606-612. doi: 10.1007/s00128-010-0007-z
Singh, R. P., Gupta, A. K., Ibrahim, M. H., and Mittal, A. K. (2010). Coal fly ash utilization in agriculture: its potential benefits and risks. Rev. Environ. Sci. Biol. 9, 345-358. doi: 10.1007/s11157-010-9218-3

Singh, R. P., Sharma, B., Sarkar, A., Sengupta, C., Singh, P., and Ibrahim, M. H. (2014). Biological responses of agricultural soils to fly-ash amendment. Rev. Environ Contam. Toxicol. 232, 45-60. doi: 10.1007/978-3-319-06746-9_2

Singh, R. P., Singh, P., Araujo, A. S., Ibrahim, M. H., and Sulaiman, O. (2011). Management of urban solid waste: vermicomposting a sustainable option. Resour. Conserv. Recycling 55, 719-729. doi: 10.1016/j.resconrec.2011.02.005

Singh, R. P., Singh, P., Ibrahim, M. H., and Hashim, R. (2012). Land application of sewage sludge: physicochemical and microbial response. Rev. Environ. Contam. Toxicol. 214, 41-61. doi: 10.1007/978-1-4614-0668-6_3

Singh, U. K., and Kumar, B. (2017). Pathways of heavy metals contamination and associated human health risk in Ajay River basin, India. Chemosphere 174, 183-199. doi: 10.1016/j.chemosphere.2017.01.103

Šmejkalová, M., Mikanova, O., and Boruvka, L. (2003). Effects of heavy metals concentrations on biological activity of soil microorganisms. Plant Soil Environ. 49, 321-326.

Srivastava, V., de Araujo, A. S. F., Vaish, B., Bartelt-Hunt, S., Singh, P., and Singh, R. P. (2016). Biological response of using municipal solid waste compost in agriculture as fertilizer supplement. Rev. Environ. Sci. Biol. 15, 677-696. doi: 10.1007/s11157-016-9407-9

Srivastava, V., Ismail, S. A., Singh, P., and Singh, R. P. (2015). Urban solid waste management in the developing world with emphasis on India: challenges and opportunities. Rev. Environ. Sci. Biol. 14, 317-337. doi: 10.1007/s11157-014-9352-4

Steinkellner, H., Mun-Sik, K., Helma, C., Ecker, S., Ma, T. H., Horak, O., et al. (1998). Genotoxic effects of heavy metals: comparative investigation with plant bioassays. Environ. Mol. Mutagen. 31, 183-191. doi: 10.1002/(SICI)10982280(1998)31:2\&lt;183::AID-EM11\&gt;3.0.CO;2-8

Sun, C., Liu, J., Wang, Y., Sun, L., and Yu, H. (2013). Multivariate and geostatistical analyses of the spatial distribution and sources of heavy metals in agricultural soil in Dehui, Northeast China. Chemosphere 92, 517-523. doi: 10.1016/j.chemosphere.2013.02.063

Takemura, T., Hanagata, N., Sugihara, K., Baba, S., Karube, I., and Dubinsky, Z. (2000). Physiological and biochemical responses to salt stress in the mangrove, Bruguiera gymnorrhiza. Aquat. Bot. 68, 15-28. doi: 10.1016/S0304-3770(00)00106-6

Tamás, L., Mistrík, I., and Zelinová, V. (2017). Heavy metal-induced reactive oxygen species and cell death in barley root tip. Environ. Exp. Bot. 140, 34-40. doi: 10.1016/j.envexpbot.2017.05.016

Taylor, M. D., and Percival, H. J. (2001). Cadmium in soil solutions from a transect of soils away from a fertilizer bin. Environ. Pollut. 113, 35-40. doi: 10.1016/S0269-7491(00)00170-6

Thakur, S., Singh, L., Ab Wahid, Z., Siddiqui, M. F., Atnaw, S. M., and Din, M. F. M. (2016). Plant-driven removal of heavy metals from soil: uptake, translocation, tolerance mechanism, challenges, and future perspectives. Environ. Monit. Assess. 188:206. doi: 10.1007/s10661-016-5211-9

Thapa, G., Sadhukhan, A., Panda, S. K., and Sahoo, L. (2012). Molecular mechanistic model of plant heavy metal tolerance. Biometals 25, 489-505. doi: 10.1007/s10534-012-9541-y

Thounaojam, T. C., Panda, P., Mazumdar, P., Kumar, D., Sharma, G. D., Sahoo, L., et al. (2012). Excess copper induced oxidative stress and response of antioxidants in rice. Plant Physiol. Biochem. 53, 33-39. doi: 10.1016/j.plaphy.2012.01.006

Tóth, G., Hermann, T., Da Silva, M. R., and Montanarella, L. (2016). Heavy metals in agricultural soils of the European Union with implications for food safety. Environ. Pollut. 88, 299-309. doi: 10.1016/j.envint.2015.12.017

Turton, H. E., Dawes, I. W., and Grant, C. M. (1997). Saccharomyces cerevisiae exhibits a yAP-1-mediated adaptive response to malondialdehyde. J. Bacteriol. 179, 1096-1101. doi: 10.1128/jb.179.4.1096-1101.1997

Tyler, G. (1975). "Effect of heavy metal pollution on de-composition and mineralization rates in forest soil," in Heavy Metals in the Environment, eds T. C. Hutchinson, A. L. Page, and J. C. Loon (Toronto, ON), 217-226.

Ueno, D., Iwashita, T., Zhao, F. J., and Ma, J. F. (2008). Characterization of $\mathrm{Cd}$ translocation and identification of the $\mathrm{Cd}$ form in xylem sap of the Cd-hyperaccumulator Arabidopsis halleri. Plant Cell Physiol. 49, 540-548. doi: $10.1093 / \mathrm{pcp} / \mathrm{pcn} 026$ 
Van de Poel, B., Smet, D., and Van Der Straeten, D. (2015). Ethylene and hormonal crosstalk in vegetative growth and development. Plant Physiol. 169, 61-72. doi: $10.1104 /$ pp.15.00724

Vanhoudt, N., Vandenhove, H., Horemans, N., Remans, T., Opdenakker, K., Smeets, K., et al. (2011). Unraveling uranium induced oxidative stress related responses in Arabidopsis thaliana seedlings. Part I: responses in the roots. J. Environ. Radioact. 102, 630-637. doi: 10.1016/j.jenvrad.2011.03.015

Vásquez-Murrieta, M. S., Migueles-Garduño, I., Franco-Hernández, O., Govaerts, B., and Dendooven, L. (2006). C and N mineralization and microbial biomass in heavy-metal contaminated soil. Eur. J. Soil Biol. 42, 89-98. doi: 10.1016/j.ejsobi.2005.10.002

Venkatachalam, P., Jayalakshmi, N., Geetha, N., Sahi, S. V., Sharma, N. C., Rene, E. R., et al. (2017). Accumulation efficiency, genotoxicity and antioxidant defense mechanisms in medicinal plant Acalypha indica L. under lead stress. Chemosphere 171, 544-553. doi: 10.1016/j.chemosphere.2016.12.092

Verkleij, J. A. (1993). "The effects of heavy metals stress on higher plants and their use as bio monitors,", in Plant as Bioindicators: Indicators of Heavy Metals in the Terrestrial Environment, ed B. Markert (New York, NY: VCH), 415-424.

Viehweger, K. (2014). How plants cope with heavy metals. Bot. Stud. 55:35. doi: 10.1186/1999-3110-55-35

Wang, C., Knill, E., Glick, B. R., and Defago, G. (2000). Effect of transferring 1-amino-cyclopropane-1-carboxylic acid (ACC) deaminase genes into Pseudomonas fluorescens strain CHAO and its gacA derivative CHA96 on their growth-promoting and disease-suppressive capacities. Can. J. Microbiol. 46, 898-907. doi: 10.1139/w00-071

Wang, J., Zhao, F. J., Meharg, A. A., Raab, A., Feldmann, J., and McGrath, S. P. (2002). Mechanisms of arsenic hyperaccumulation in Pterisvittata. Uptake kinetics, interactions with phosphate, and arsenic speciation. Plant physiol. 130, 1552-1561. doi: 10.1104/pp.008185

Wang, L., Yang, L., Yang, F., Li, X., Song, Y., Wang, X., et al. (2010). Involvements of $\mathrm{H} 2 \mathrm{O} 2$ and metallothionein in NO-mediated tomato tolerance to copper toxicity. J. Plant Physiol. 167, 1298-1306. doi: 10.1016/j.jplph.2010.04.007

Wang, Y. P., Shi, J. Y., Wang, H., Lin, Q., Chen, X. C., and Chen, Y. X. (2007). The influence of soil heavy metals pollution on soil microbial biomass, enzyme activity, and community composition near a copper smelter. Ecotoxicol. Environ. Saf. 67, 75-81. doi: 10.1016/j.ecoenv.2006.03.007

Wang, Y., Li, Q., Shi, J., Lin, Q., Chen, X., Wu, W., et al. (2008). Assessment of microbial activity and bacterial community composition in the rhizosphere of a copper accumulator and a non accumulator. Soil Biol. Biochem. 40, 1167-1177. doi: 10.1016/j.soilbio.2007.12.010

Wang, Y., Shen, H., Xu, L., Zhu, X., Li, C., Zhang, W., et al. (2015). Transport, ultrastructural localization, and distribution of chemical forms of lead in radish (Raphanus sativus L.). Front. Plant Sci. 6:293. doi: 10.3389/fpls.2015.00293

Wei, B., and Yang, L. (2010). A review of heavy metal contaminations in urban soils, urban road dusts and agricultural soils from China. Microchem. J. 94, 99-107. doi: 10.1016/j.microc.2009.09.014

Wojas, S., Clemens, S., SkŁodowska, A., and Antosiewicz, D. M. (2010). Arsenic response of AtPCS1- and CePCS-expressing plants-effects of external As (V) concentration on As-accumulation pattern and NPT metabolism. J. Plant Physiol. 167, 169-175. doi: 10.1016/j.jplph.2009.07.017

Woldetsadik, D., Drechsel, P., Keraita, B., Itanna, F., and Gebrekidan, H. (2017). Heavy metal accumulation and health risk assessment in wastewater-irrigated urban vegetable farming sites of Addis Ababa, Ethiopia. Int. J. Food Contam. 4:9. doi: 10.1186/s40550-017-0053-y

Wonisch, W., Hayn, M., Schaur, R. J., Tatzber, F., Kranner, I., Grill, D., et al. (1997). Increased stress parameter synthesis in the yeast Saccharomyces cerevisiae after treatment with 4-hydroxy-2-nonenal. FEBS Lett. 405, 11-15. doi: 10.1016/S0014-5793(97)00123-3

Xian, Y., Wang, M., and Chen, W. (2015). Quantitative assessment on soil enzyme activities of heavy metal contaminated soils with various soil properties. Chemosphere 139, 604-608. doi: 10.1016/j.chemosphere.2014.12.060

Xiong, L., and Yang, Y. (2003). Disease resistance and abiotic stress tolerance in rice are inversely modulated by an abscisic acid-inducible mitogen-activated protein kinase. Plant Cell 15, 745-759. doi: 10.1105/tpc.008714
Xu, X., Zhao, Y., Zhao, X., Wang, Y., and Deng, W. (2014). Sources of heavy metal pollution in agricultural soils of a rapidly industrializing area in the Yangtze Delta of China. Ecotoxicol. Environ. Saf. 108, 161-167. doi: 10.1016/j.ecoenv.2014.07.001

Yang, J. L., Wang, L. C., Chang, C. Y., and Liu, T. Y. (1999). Singlet oxygen is the major species participating in the induction of DNA strand breakage and 8-hydroxydeoxyguanosine adduct by lead acetate. Environ. Mol. Mutagen. 33, 194-201. doi: 10.1002/(SICI)1098-2280(1999)33:3<194::AID-EM3>3.0.CO;2-O

Yanqun, Z., Yuan, L., Jianjun, C., Haiyan, C., Li, Q., and Schvartz, C. (2005). Hyperaccumulation of $\mathrm{Pb}, \mathrm{Zn}$ and $\mathrm{Cd}$ in herbaceous grown on lead-zinc mining area in Yunnan, China. Environ. Int. 31, 755-762. doi: 10.1016/j.envint.2005.02.004

Yeh, C. M., Hung, W. C., and Huang, H. J. (2003). Copper treatment activates mitogen-activated protein kinase signalling in rice. Physiol. Plant. 119, 392-399. doi: 10.1034/j.1399-3054.2003.00191.x

Yuan, L., Zhi, W., Liu, Y., Karyala, S., Vikesland, P. J., Chen, X., et al. (2015). Lead toxicity to the performance, viability, and community composition of activated sludge microorganisms. Environ. Sci. Technol. 49, 824-830. doi: $10.1021 /$ es504207c

Zaffagnini, M., Bedhomme, M., Lemaire, S. D., and Trost, P. (2012). The emerging roles of protein glutathionylation in chloroplasts. Plant Sci. 185, 86-96. doi: 10.1016/j.plantsci.2012.01.005

Zahra, A., Hashmi, M. Z., Malik, R. N., and Ahmed, Z. (2014). Enrichment and geo-accumulation of heavy metals and risk assessment of sediments of the Kurang Nallah-feeding tributary of the Rawal Lake Reservoir, Pakistan. Sci. Tot. Environ. 470, 925-933. doi: 10.1016/j.scitotenv.2013.10.017

Zhang, F. P., Li, C. F., Tong, L. G., Yue, L. X., Li, P., Ciren, Y. J., et al. (2010). Response of microbial characteristics to heavy metal pollution of mining soils in central Tibet, China. Appl. Soil Ecol. 45, 144-151. doi: 10.1016/j.apsoil.2010.03.006

Zhang, F. Q., Wang, Y. S., Lou, Z. P., and Dong, J. D. (2007). Effect of heavy metal stress on antioxidative enzymes and lipid peroxidation in leaves and roots of two mangrove plant seedlings (Kandelia candel and Bruguiera gymnorrhiza). Chemosphere 67, 44-50. doi: 10.1016/j.chemosphere.2006.10.007

Zhang, H. Y., Jiang, Y. N., and He, Z. Y. (2005). Cadmium accumulation and oxidative burst in garlic (Allium sativum). J. Plant Physiol. 162, 977-984. doi: 10.1016/j.jplph.2004.10.001

Zhang, S., and Klessig, D. F. (2001). MAPK cascades in plant defense signaling. Trends Plant Sci. 6, 520-527. doi: 10.1016/S1360-1385(01)02103-3

Zhou, T., Li, L., Zhang, X., Zheng, J., Joseph, S., and Pan, G. (2016). Changes in organic carbon and nitrogen in soil with metal pollution by $\mathrm{Cd}, \mathrm{Cu}$, $\mathrm{Pb}$ and $\mathrm{Zn}$ : a meta-analysis. Eur. J. Soil Sci. 67, 237-246. doi: 10.1111/ejss. 12327

Zhu, C., Tian, H., Cheng, K., Liu, K., Wang, K., Hua, S., et al. (2016). Potentials of whole process control of heavy metals emissions from coal-fired power plants in China. J. Clean Prod. 114, 343-351. doi: 10.1016/j.jclepro.2015. 05.008

Zverina, O., Láska, K., Cervenka, R., Kuta, J., Coufalík, P., and Komárek, J. (2014). Analysis of mercury and other heavy metals accumulated in lichen Usnea antarctica from James Ross Island, Antarctica. Environ. Monit. Assess. 186, 9089-9100. doi: 10.1007/s10661-014-4068-z

Conflict of Interest Statement: The authors declare that the research was conducted in the absence of any commercial or financial relationships that could be construed as a potential conflict of interest.

Copyright (c) 2017 Srivastava, Sarkar, Singh, Singh, de Araujo and Singh. This is an open-access article distributed under the terms of the Creative Commons Attribution License (CC BY). The use, distribution or reproduction in other forums is permitted, provided the original author(s) or licensor are credited and that the original publication in this journal is cited, in accordance with accepted academic practice. No use, distribution or reproduction is permitted which does not comply with these terms. 